\title{
CONSPIRACY, CONCEALMENT AND THE STATUTE OF LIMITATIONS
}

As an "elastic, sprawling, and pervasive offense . . . so vague that it almost defies definition," federal conspiracy law ${ }^{2}$ is hard to smooth into the doctrinal folds of a criminal code which conceives itself as giving the world "fair warning ... of what the law intends to do if a certain line is passed."3 Com-

1. Krulewitch v. United States, 336 U.S. 440, 445-46 (1946) (Jackson, J., concurring).

2. Ordinarily, federal conspiracy prosecutions are brought under 18 U.S.C. $\$ 371$ (1958), which provides that

If two or more persons conspire either to commit any offense against the United States, or to defraud the United States, or any agency thereof in any manner or for any purpose, and one or more of such persons do any act to effect the object of the conspiracy, each shall be fined not more than $\$ 10,000$ or imprisoned not more than five years, or both.

If, however, the offense, the commission of which is the object of the conspiracy, is a misdemeanor only, the punishment for such conspiracy shall not exceed the maximum punishment provided for such misdemeanor.

Especial attention should be paid to the "either-or" construction of the statute; to conspire "to commit an offense against the United States" means to conspire to commit a substantive crime elsewhere defined in the code. E.g., 18 U.S.C. \& 2113 (1958) defines the crime of robbing a federally insured bank; a conspiracy to rob such a bank would be indicted under $\S \S 371,2113$.

A conspiracy "to defraud," on the other hand, need not have as its object an offense elsewhere defined, the gist of the behavior outlawed deriving its content largely from prior court decisions. See, e.g., Hammerschmidt v. United States, 265 U.S. 182 (1924), Haas v. Henkel, 216 U.S. 462 (1910). See generally A. Goldstein, Conspiracy to Defraud the United States, 68 Yare L.J. 405 (1959).

The requirement that the conspirators must have committed an "act to effect the object of the conspiracy" before the crime is complete is a refinement on traditional conspiracy law, designed to afford the conspirators a locus poenitentiae. United States v. Britton, 108 U.S. 199, 204-05 (1883).

For conspiracies which may be indicted specially, without recourse to $\S 371$, see 18 U.S.C. $\$ \S 372$ (to impede or injure a federal officer), 2385 (to advocate the overthrow of the government), 793 (to gather or transmit defense information), 794 (to commit espionage), 2155 (to destroy national defense materials), 2384 (to commit sedition) (destruction of national defense materials), 2153 (to commit sabotage), 1201 (to kidnap), 1792 (to incite convicts to mutiny), 2192 (to incite seamen to mutiny), 956 (to injure property of foreign government), 241 (to violate civil rights) (1958). See also 42 U.S.C. $\$ \$ 2272,2273$, 2274, 2277 (1958), 68 Stat. 958, 959 (1954) (relating to atomic energy), 1985 (1958), Rev. Stat. § 1980 (1875) (relating to civil rights); 62 Stat. 1074 (1948), as amended, 15 U.S.C. \$ 714m (1958) (relating to Commodity Credit Corporation law); 26 U.S.C. \$ 7214 (relating to internal revenue); 16 U.S.C. \& 831t (relating to Tennessee Valley Authority); 50 U.S.C. $\S \S 822-24,783$, and $\S \S 462,1963$ (relating to national defense); 31 U.S.C. § 231 (false claims against government); 10 U.S.C. § 881 (relating to military offenses); 15 U.S.C. $\S \S 1-3,8$ (relating to restraint of trade). The latest addition to this list is 47 U.S.C. $\$ 509$ (Supp. II 1959-60) (relating to rigged quiz shows).

3. McBoyle v. United States, 283 U.S. 25 (1931). Conviction for transporting stolen 
ment has previously been made that the uncertain and shadowy lines of conspiracy offer poor warning as to what sort of behavior one is forbidden to engage in. ${ }^{4}$ But there is another dimension to the ominously plastic contours of the crime which seems to have escaped notice $:^{5}$ not only is it still unsettled what acts constitute a conspiracy, but it is unclear when a conspiracy terminates. A clear delineation of the time-scope of a conspiracy is essential, ${ }^{6}$ for the tendency of the crime to be an "instrument of injustice"" increases with its duration. The longer the conspiracy is deemed alive, the greater the number of "conspirators" who may be swept within its "dragnet path." Moreover,

airplane interstate under a statute which related to "motor vehicles" was reversed by Holmes, J.:

To make the warning fair, so far as possible the line should be clear. When a rule of conduct is laid down in words that evoke in the common mind only the picture of vehicles moving on land, the statute should not be extended to aircraft, simply because it may seem to us that a similar policy applies, or upon the speculation that, if the legislature had thought of it, very likely broader words would have been used.

Id. at 27.

But for a strikingly divergent attitude toward vagueness, see Boyce Motor Lines v. United States, 342 U.S. 337 (1952).

4. See, e.g., Goldstein, Conspiracy to Defrand the United States, 68 YALE L.J. 405 (1959); Klein, Conspiracy-The Prosecutor's Darling, 24 BRookLXN L. REv. 1 (1957); Harno, Intent in Criminal Conspiracy, 89 U. PA. I. Rev. 624 (1941) ; Holdsworth, Conspiracy and Abuse of Legal Process, 37 L.Q. Rev. 462 (1921); Note, 62 Harv. L. Rev. 276 (1948).

5. But see Model Penal Code $\$ 5.03$ (Tent. Draft No. 10, 1960).

6. The objection to leaving unresolved the time-scope a conspiracy is but a corollary to criticisms of the ill-defined scope of conspiracy in general. See United States v. Falcone, 109 F.2d 579 (2d Cir. 1940) :

... [S] many prosecutors seek to sweep within the dragnet of conspiracy all those who have been associated in any degree whatever with the main offenders. That there are opportunities of great oppression in such a doctrine is very plain, and it is only by circumscribing the scope of all such comprehensive indictments that they Id. at 581 . can be avoided.

See O'Brian, Loyalty Tests and Guilt by Association, 61 HARv. I. Rev. 592, 599 (1948) ("special attention should be given to the sinister developments which have been taking place in broadening the scope of our criminal conspiracy statutes").

7. Dennis v. United States, 341 U.S. 494, 572 (1951) (Jackson, J., concurring).

8. See Skelly v. United States, 76 F.2d 483 (10th Cir. 1935), cert. denied, 295 U.S. 757 (1935); Laska v. United States, 82 F.2d 672 (10th Cir. 1936), cert. denied, 298 U.S. 689 (1936) ; McDonald v. United States, 89 F.2d 128 (8th Cir. 1937), cert. dcnied, 301 U.S. 697 (1937), rehearing denied, 302 U.S. 773 (1937), pet. for writ of error coram nobis denied, 303 U.S. 622 (1938), writ of habeas corpus denied sub non. Hudspeth v. MCDonald, 120 F.2d 962 (10th Cir. 1941), pet. for rehearing and other relief denied, 325 U.S. 892 (1945). In these three cases defendants were convicted of conspiracy to kidnap despite the fact that their association with the kidnappers did not begin until after the kidnap victim had been exchanged for ransom.

See also Rettich v. United States, 84 F.2d 118 (1st Cir. 1936) (conspiracy to rob mails). But cf. Bollenbach v. United States, 326 U.S. 607, 611 (1946). 
forestalling the time at which a conspiracy is said to have "ended" may have a critical effect upon some fundamental aspects of criminal procedure. The constitutional guarantee to be tried in the judicial district "wherein the crime shall have been committed"9 has been construed to allow the trial to be held wherever any of the conspirators performed an overt act in furtherance of (and, hence, during the pendency of) the conspiracy..$^{10}$ Hearsay acts and declarations of one conspirator are admissible against all the conspirators only if they occurred in furtherance of the conspiracy, not if they occurred after it has terminated. ${ }^{11}$ Most important, the statute of limitations ${ }^{12}$ does not begin to run until the performance of the last overt act "in furtherance of" the conspiracy. ${ }^{13}$ Because the consequences of extending the operative life of a

9. U.S. CoNsr. amend. VI. "In all criminal prosecutions, the accused shall enjoy the right to a speedy and public trial, by an impartial jury of the State and district wherein the crime shall have been committed, which district shall previously have been ascertained by law."

10. Brown v. Elliot, 225 U.S. 392 (1912), held that each overt act, though not necessarily a crime in itself, gave the government another choice of venue within the meaning of the sixth amendment.

See generally Blume, The Place of Trial of Crimiral Cases, 43 Mrce. L. REv. 59 (1944) ; 1 Holares-Pollock Letrers $193-99$ (Howe ed. 1941). See also text at notes 192200 infra.

11. Fiswick v. United States, 329 U.S. 211 (1946) ; Logan v. United States, 144 U.S. 263, 308-09 (1892). See Levie, Hearsay and Conspiracy, 52 MICH. L. REv. 1159 (1954); Note, 40 J. Am. Inst. Crm. L. \& Crimtnology 760 (1950); Modez Code of Entdence rule 508 (1942) and text at notes 179-201 infra.

12. 18 U.S.C. $\S 3282$ (1958). "Except as otherwise expressly provided by law, no person shall be prosecuted, tried, or punished for any offense, not capital, unless the indictment is found or the information is instituted within five years next after such offense shall have been committed."

Prior to the amendment of September 1, 1954, added by 68 Stat. 1145 (1954), a three year period of limitations was applicable, and most of the cases considered herein arose under the shorter period. For a period "otherwise expressly provided by law," see, e.g., 64 Stat. 991 (1950), 50 U.S.C. $\S 783$ (e) (1958), which provides a ten year period for conspiracies to establish totalitarian dictatorships, and related offenses against the national defense. The statute does not run while the suspect is a fugitive from justice. 18 U.S.C. $\S 3290$ (1958) ; Donnell v. United States, 229 F.2d 560 (5th Cir. 1956). For certain offenses, including conspiracy to defraud, the statute is suspended in wartime and until the cessation of hostilities. 18 U.S.C. $\$ 3287$ (1958); United States v. Lurie, 222 F.2d 11 (7th Cir. 1955), cert. denied, 350 U.S. 835 (1955).

Under 18 U.S.C. $\$ 371$ (1958), conspiracies to commit a substantive offense have a period of limitations no longer than that of the substantive offense itself. See United States v. Albanese, 123 F. Supp. 732,735 (S.D.N.Y. 1954). Cf. Bridges v. United States, 346 U.S. 209, 223 (1953).

See Note, 102 U. PA. L. REv. 630 (1954); see also notes $134-78$ infra and accompanying text.

13. Grunewald v. United States, 353 U.S. 391 (1957) ; Hyde v. United States, 225 U.S. 347 (1912).

The earliest federal courts to deal with the question had held that the first overt act in furtherance of the conspiracy marked the beginning of the statute of limitations period, on the view that the crime was then "complete," i.e., the conspirators could then have been 
conspiracy are felt in so many ways, and because of the popularity which conspiracy prosecutions enjoy with the government-Learned Hand once called the crime "that darling of the modern prosecutor's nursery"14-recent developments threatening to extend the duration of a conspiracy deserve the closest attention.

The prosecution's efforts to stave off the time at which a conspiracy legally terminates have, in recent years, branched off into two doctrinally distinguishable approaches. Both seize upon acts of concealment to prove the continuance of the crime. One approach urges that an alleged agreement to conceal is ancillary to and extends the duration of a conspiracy to commit a substantive offense. ${ }^{15}$ The other approach, rather than to seek conviction for complicity in some substantive crime, urges the same agreement to conceal as in itself an indictable conspiracy "to defraud the United States."16 To illustrate, suppose that $A, B$ and $C$ conspire to, and do kidnap $X$. Obtaining their ransom, they proceed to release him. Thereafter, afraid that the ransom was paid in identifiable currency, they approach $D$, who, knowing of the kidnapping, agrees to aid them in avoiding detection by exchanging the ransom for unmarked bills. On these facts, the prosecution, under the first approach, would allege that the conspirators originally agreed (1) to kidnap $X$ and (2) to conceal the kidnapping by disposing of the marked bills, and that both phases of the plan were embraced in a single conspiracy to kidnap. A foundation would thus be laid for the argument that the conspiracy to kidnap was in existence beyond the time of releasing the kidnap victim, and lasted at least through the time of disposing of the ransom. So conceived, $D$ would be a principal in the conspiracy to kidnap (rather than a mere accessory after the fact), ${ }^{17}$ even though he was not aware of the existence of the conspiracy until after $X$ 's release. The statute of limitations, instead of running from the time of releasing $X$, would begin to run at the exchange of the currency. Hearsay acts and declarations of $A, B, C$ and $D$, made between the time of releasing $X$ and the exchange of the currency, would be admissible in evidence against all the con-

indicted. See, e.g., United States v. Owen, 32 Fed. 534 (D. Ore. 1887) ; United States v. McCord, 72 Fed. 159 (W.D. Wis. 1906); Ex parte Black, 147 Fed. 832 (E.D. Wis. 1906), aff'd sub nom. United States v. Black, 160 Fed. 431 (7th Cir. 1908); United States v. Biggs, 157 Fed. 264 (D. Colo. 1907), aff'd, 211 U.S. 507 (1909) (but expressly refusing to pass on the time at which the statute begins to run). This early view was clearly on the wane after a strong contrary holding in Ware v. United States, 154 Fed. 577 (8th Cir. 1907).

14. Harrison v. United States, 7 F.2d 259, 263 (2d Cir. 1925).

15. See discussions of Krulewitch v. United States, 336 U.S. 440 (1949) in text at notes 23-39 infra; Lutwak v. United States, 344 U.S. 604 (1953) in text at notes 48-63 infra; and Grunewald v. United States, 353 U.S. 391 (1957) in text at notes 64-104 infra.

16. 18 U.S.C. $\$ 371$ (1958). See note 2 supra. See discussions of United States v. Klein, 247 F.2d 908 (2d Cir. 1957), cert. denied, 355 U.S. 924 (1958) in text at notes 111-32 infra, and United States v. Bonnano, 177 F. Supp. 106 (S.D.N.Y. 1959) in text at notes 156-63 infra, rez'd sub nom. United States v. Bufalino, 285 F.2d 408 (2d Cir. 1960) in text at notes 228-30 infra.

17. 18 U.S.C. $\S 3$ (1958), and cf. 18 U.S.C. $\S 1202$ (1958), both set out in note 214 infra. 
spirators. And any judicial district wherein ransom was exchanged would be a possible venue.

Under the second approach, in lieu of alleging that the concealment extended the conspiracy to kidnap, the same acts of exchanging the ransom bills are fashioned into an independent conspiracy to defraud the United States on the theory that they obstruct the government's efforts to investigate the kidnapping. If a conspiracy to conceal may thus be construed as itself a violation of the conspiracy to defraud statute, then each new act of concealment assumes the status of an overt act proving the continued existence of the very crime "defined" by Congress, and may not be dismissed as a legally inoperative cover-up of a past offense. Thus, if $A, B, C$ and $D$ were charged with a conspiracy to defraud, they would, as under the first approach, remain members of an illegal conspiracy even after the kidnap victim had been released. In fact, it appears possible that $A, B, C$ and $D$ could be convicted of a conspiracy to defraud, even if the prosecution is unable to prove that they did in fact commit a kidnapping - on the theory that they prevented the government from finding out whether or not they had done so. ${ }^{18}$

In their effective impact upon the statute of limitations, hearsay and venue, the two approaches do not differ..$^{10}$ Each, alike, has aroused judicial wariness. ${ }^{20}$ Yet, since these two approaches demand acceptance from conceptually independent angles, in that each is able to rally its own maxims in support, it is possible that one theory, if not both, will be able to sift through judicial scrutiny to become firmly embedded in the law.

Before either of these theories can be commended to final approval, the Supreme Court ought to satisfy itself upon a number of issues. Does the use of acts of concealment conceptually to extend the time at which the offense is "committed" violate the letter or the spirit of an applicable statute of limitations? And once a conspirator has concealed something, how may he bring his criminal behavior to an end so that the statute will start to run? With regard to venue, ought an act of concealment performed far from the situs of the

18. See discussion of United States v. Klein, 247 F.2d 908 (2d Cir. 1957), cert. denied, 355 U.S. 924 (1958) in text at notes 111-32 infra.

19. Because 18 U.S.C. $\$ 371$ (1958) supports indictments for conspiracy to commit the substantive offense (the "first approach" in the text) and for conspiracy to defraud (the "second approach"), even the penalties the two approaches entail will generally be the same, ;viz., the five years and $\$ 10,000$ prescribed by $\$ 371$. The example in the text is one of the exceptions in that conspiracy to kidnap is indictable under a separate provision, 18 U.S.C. $\S 1201$ (c) (1958). Because $\S 1201$ (c) allows penalties as high as death or life imprisonment, an indictment under the first approach could entail more severe sanctions than an indictment under the second approach.

20. See the discussion of Grunewald v. United States, 353 U.S. 391 (1957) at notes 94, 95, 103 infra, and the analysis of that case in Forman v. United States, 259 F.2d 128, 133-35 (9th Cir. 1958). Compare the concurring opinion of Judge Clark in United States v. Bufalino, 185 F.2d 408 (2d Cir. 1960), reversing United States v. Bonnano, 177 F. Supp. 106 (S.D.N.Y. 1959), with the earlier holding, also written by Judge Clark, in United States v. Klein, 247 F.2d 908 (2d Cir. 1957), cert. denied, 355 U.S. 924 (1958). 
substantive offense justify what Holmes called "the hardship and injustice of snaking a man across the continent for trial?"21 Should the courts reject the "further breach of the general rule against the admission of hearsay evidence"22 which would be a consequence of either conspiracy theory? Or should it be welcomed as opening the door to a more rational means of sifting evidence? If acts of concealment are to extend the duration of a conspiracy at all, should its extension be permitted indiscriminately for venue, evidence, and statute of limitations purposes? Or should each be treated separately? On the other hand, in determining whether a separate conspiracy to defraud should be fashioned out of acts of concealment, what kinds of concealment ought to support such a charge? How far beyond the forms of interference with governmental functions specifically proscribed by acts of Congress should the courts reach in applying the conspiracy concept?

\section{Concealment and the Courts}

\section{Krulezvitch: The Problem Posed}

The Supreme Court's reluctance definitively to establish the temporal reach of a conspiracy is illustrated by Krulewitch $v$. United States. ${ }^{23}$ Krulewitch and his co-defendant were convicted of conspiracy to transport a woman "in interstate commerce" for purposes of prostitution. ${ }^{24}$ One and one-half months after her trip from New York to Miami, the complaining witness was visited by Krulewitch's alleged co-conspirator, a woman, who made a statement manifesting an attempt to conceal Krulewitch's role in the crime. ${ }^{25}$ At trial, the complaining witness was allowed to narrate the conversation on the grounds that it has been made "in furtherance" of the conspiracy, and thus fell within the co-conspirator's exception to the hearsay rule. ${ }^{26}$ In reviewing the case,

21. 1 Holmes-Pollock LetTers 193-94 (Howe ed. 1941), commenting on Brown v. Elliot, 225 U.S. 292 (1912).

22. Krulewitch v. United States, 336 U.S. 440, 444 (1949).

23. 336 U.S. 440 (1949).

24. The indictment charged conspiracy under 18 U.S.C. \& 88 [now 18 U.S.C. § 371 (1958)] to violate 18 U.S.C. $\$ \S 298-99$ [now 18 U.S.C. $\$ \S 2421-22$ (1958)].

25. The complaining witness testified:

"She asks me, she says 'you didn't talk yet?' And I says, 'No.' And she says, 'Well, don't,' she says, 'until we get you a lawyer.' And then she says, 'Be very careful what you say.' And I can't put it in exact words. But she said, 'It would be better for us two girls to take the blame than Kay (the Defendant) because he couldn't stand it, he couldn't stand to take it.'"

336 U.S. at 441.

26. Actually, the trial judge seems to have admitted the testimony on the grounds that any act or declaration of a co-conspirator was admissible, either before or after the conspiracy, to show intent. Record, p. 111. The government imputed to him the more conservative rationale before the Supreme Court (See, e.g., "Questions Presented ............ 3. Whether statements of a codefendant not on trial, made subsequent to the interstate journey alleged in the indictment, but designed to conceal petitioner's complicity in the conspiracy charged, were properly admitted in evidence against him as declarations of a 
the Court might have said that, as a matter of law, the conspiracy could not have continued after the woman ceased to be in interstate commerce. ${ }^{27}$ Instead, the court was able to avoid meeting the doctrinal issue head-on by reversing the convictions upon the narrower ground that the government had failed to plead acts of concealment as part of the alleged conspiracy.

In the view the government had taken of the case, specially pleading that the conspiratorial agreement embraced acts of concealment was unnecessary because "implicit in a conspiracy to violate the law . . . is an agreement among the conspirators to conceal the violation after as well as before the illegal plan is consummated."28 The petitioners rejoined by claiming that even had they agreed to conceal, in legal contemplation "the minute that that transportation was at an end the conspiracy was at an end" and that no act thereafter could have been in furtherance of the crime. ${ }^{29}$ But the government pointed to several lower court cases which had rejected just such a contention. ${ }^{30}$ Most nearly in point was Lew Moy v. United States, ${ }^{31}$ a prosecution for conspiracy to violate the immigration laws by bringing into the country certain aliens not entitled to entry. There, similarly, the defendants had objected to the introduction of acts and declarations of one of the conspirators occurring after the aliens had been brought across the national boundary. But the court in Lew Moy had answered that "this is too narrow a view of the crime charged," saying

Successfully to consummate the unlawful introduction of the prohibited aliens required more than the mere bringing of them across the line. It

co-conspirator in furtherance of the conspiracy." Brief for the United States in Opposition to Certiorari, p. 2. The case was thus argued before the Supreme Court. Cf. 336 U.S. at 442-43. But as regards the position the trial judge took, see note 63 infra.

27. See case at note 40 infra and accompanying text, and cases cited in notes $46-47$ infra.

28. Brief for the United States in Opposition to Certiorari, p. 14, quoting from United States v. Krulewitch, 167 F.2d 943, 948 (2d Cir. 1948).

29. Record, pp. 110-11, 336 U.S. 440 (1949). See Brief for Petitioner, p. 10. Before the Supreme Court, petitioner emphasized that at the time of the visit defendant and codefendant were already under arrest, and that the arrest should have terminated the conspiracy, whether or not the cessation of interstate commerce had done so. Id. at 9.

30. In addition to Lew Moy, the Government relied on United States v. Goldstein, 135 F.2d 359, 361-62 (2d Cir. 1943) (in prosecution for conspiracy to defraud the government of taxes on distilled spirits, statement made by co-conspirator after the still had been seized held admissible on grounds that, even if conspirators could no longer be conspiring to defraud by operating still, they could be conspiring to avoid detection of the fraud which was the gist of the conspiracy) ; Skelly v. United States, 76 F.2d 483 (10th Cir. 1935), at note 8 supra; and Murray v. United States, 10 F.2d 409 (7th Cir. 1925), cert. denied, 271 U.S. 673 (1926) (conspiracy to rob mail from train in interstate commerce, the court upholding the admissions of statements made after the robbery on the grounds that "among the offenses which the indictment charged as the objects of the conspiracy were the concealing and possessing of the fruits of the robbery and these crimes [sic] were going on at the time the acts were done and the declarations made." $10 \mathrm{~F} .2 \mathrm{~d}$ at 411.)

A number of state decisions supporting the Government's position are also collected in Brief for the United States, pp. 21-23, Krulewitch v. United States, 336 U.S. 440 (1949).

31. 237 Fed. 50 (8th Cir. 1916). 
was necessary to evade the immigration officials by transporting them into the interior and concealing their identity. ${ }^{32}$

But if a conspiratorial agreement be one successfully to commit a substantive offense, then it is difficult to see whether the court would ever deem the conspiracy to have terminated short of actual conviction or death of the offenders. $^{33}$ Lew Moy, however, did not stand alone in holding that courts could look beyond the statutory terms of the substantive offense in determining the possible scope of an illegal conspiracy. ${ }^{34}$ And so, in Krulezritch, the government was able to contend that the statement in issue being "plainly calculated to conceal the existence of the conspiracy from the prosecuting authorities," had been properly admitted in evidence. ${ }^{35}$

Speaking for the Court, Mr. Justice Black rejected the government's contention that "an implicit subsidiary phase of the conspiracy always survives, the phase which has concealment as its sole objective." 30 The question whether convictions might be sustained in some instances, if there were a specifically charged and proven subsidiary objective to avoid detection, was, however, left open.

Mr. Justice Jackson, in his often-quoted concurrence, was less equivocal on this question, although his answer seems somewhat incongruous. Not only did Jackson undertake a short survey of the inherent evils of conspiracy prosecutions, he went on to note that although "the modern law of conspiracy was largely evolved by judges . . . it is well and wisely settled that there can be no judge-made offense against the United States and that every prosecution must be sustained by statutory authority."37 But having advanced the principle that judges shouldn't make federal criminal law, he used it only to buttress a truism: "No statute authorizes federal judges to imply, presume, or construct a conspiracy except as one may be found from evidence."38 Surely the mandate against judicially legislated crimes could have found a more challenging target. Suppose the evidence had indicated that the conspirators had

32. Id. at 52 .

33. Of course, since the Lew Moy court faced only the question of admissibility of evidence, it is not certain that it would have allowed the prolongation of the conspiracy for the purpose of the statute of limitations or venue as well.

34. Not relied upon by the government, but also supporting the position it took, are United States v. McGuire, 64 F.2d 485 (2d Cir. 1933), cert. denied, 290 U.S. 645 (1933) (conspiracy to transport lottery tickets interstate; held, crime not committed for purposes of evidence admission "until the money the conspirators realized . . . was divided among them." (64 F.2d at 493) ; Rettich v. United States, 84 F.2d 118 (1st Cir. 1936) (conspiracy to rob mail truck did not terminate for purposes of evidence admissibility "until the final division of the loot." Id. at 121; Bellande v. United States, 25 F.2d 1 (5th Cir. 1928) (similar facts and holding); and the cases of McDonald v. United States, 89 F.2d 128 (8th Cir. 1937) and Laska v. United States, 82 F.2d 672 (10th Cir. 1936) discussed at note 8 supra.

35. Brief for the United States in Opposition to Certiorari, p. 15 n.5.

36. 336 U.S. at 443 (emphasis added).

37. 336 U.S. at $456-57$.

38. Id. at 457 (emphasis added). 
agreed to conceal the interstate transportation. Should judges construe a law which proscribes conspiring to take a woman interstate for immoral purposes as in effect prohibiting a conspiracy to transport her and thereafter to avoid detection? Jackson seems to have unquestioningly answered this in the affirmative: "Of course, if an understanding for continuous aid had been proved, it would be embraced in the conspiracy and there would be no reason to imply such an agreement." 39 Thus, by recourse to the facile but obscuring metaphor "embraced," Jackson was able to pass over a serious question of statutory construction, one which past courts had not been so ready to avoid.

The distinction between that part of a single conspiratorial agreement which is explicitly proscribed by statute and that which is not had been thoughtfully articulated by Judge, later Justice Van Devanter in Lonabaugh v. United States. ${ }^{40}$ There, the defendants were charged with conspiring (1) fraudulently to secure title to certain U.S. lands by procuring straw "entrymen" to obtain patents to the land, and, then (2) to pass the patents from the straw entrymen to their own corporation. In furtherance of the conspiracy, the entrymen had wrested title from the United States more than three years prior to the finding of the indictment, ${ }^{41}$ three years being the statutory period then applicable. ${ }^{42}$ But within three years of the indictment the conspirators had taken steps to place the title to the lands in the name of the corporation. ${ }^{43}$ The court refused to allow these last named acts to save the indictment, notwithstanding that they had been performed in furtherance of the conspirators' plan. To extend the life of the crime, "the overt act must be directed to the attainment of the object which brings the conspiracy within the interdiction; and when that object is attained 'the object of the conspiracy,' in the sense of the statute, is effected." 44 The defendants having been charged under a statute prohibiting conspiracy to defraud the United States, and the United States having been "defrauded" when it passed title, 45 the crime denounced by Congress was then terminated $;^{46}$ the acts thereafter may have been in furtherance of the conspirators' original agreement, but they could not contribute to committing the offense defined by law, and were thus incompetent to toll the running of the

39. Id. at 455-56 (emphasis added).

40. 179 Fed. 476 (8th Cir. 1910).

41. 179 Fed. at $478,479$.

42. See note 12 supra.

43. 179 Fed. at 478.

44. Id. at 481 .

45. Id. at $479-81$.

46. See also Meyer v. United States, 220 Fed. 800 (9th Cir. 1915) (conspiracy to defraud the United States; the court, citing Lonabaugh, held that the scheme to defraud was not "wholly effectuated" for statute of limitations purposes so long as ". . . there is opportunity on the part of the government to stop payment of this check."). $I d$. at 805 ; Heard v. United States, 255 Fed. 829 (8th Cir. 1919) (conspiracy to steal interstate shipments of money; statement by one co-conspirator after the robbery had taken place held inadmissible on ground that "the crime denounced by ... Congress was the stealing of the money from the express car while the money was in ... interstate commerce." 255 Fed. at 834-35). 
statute. While just such reasoning had guided the Supreme Court in circumscribing the duration of non-conspiracy offenses, ${ }^{47}$ deference to statute was not so much as adverted to in Krulewitch.

\section{Lutwak and Grunewald: Remedying the Defects}

While Krulewitch was a temporary set-back for the government, the Court had invited the possibility of unlocking the door to an ever more pervasive concept of conspiracy - if only the prosecution could discover the right key. This the government thought it had done in the subsequent case of Lutzvak v. United States. ${ }^{48} \mathrm{Had}$ Krulewitch stood for nothing more than the reluctance of the Court to sustain as a part of a conspiracy an implied but uncharged ancillary agreement to conceal, this defect could be remedied by (1) charging and (2) proving such a conspiracy. But despite the studied efforts of the government to meet the standards which Krulezwitch seemed to demand, the Court again refused to allow that the conspiracy continued beyond the date at which the substantive goal of the conspirators was achieved.

The setting for the Lutzerak prosecution was the War Brides Act, which provided that alien spouses of honorably discharged veterans could come into the country, notwithstanding any immigration quotas to the contrary. ${ }^{49}$ Three of Lutwak's relatives were Polish refugees living in Paris, and, seeing a chance to get them into this country, he and his defendant aunt entered into a "conspiracy"49a toward that end. They planned to send three honorably discharged veterans to France to marry the refugees and bring them back into the United

47. In Pendergast v. United States, 317 U.S. 412 (1942), an information charging criminal contempt was drawn so as to embrace a design (1) to induce a federal court, through misrepresentation, to effectuate a corrupt settlement of litigation and (2) to employ "continuous cooperation in concealing the scheme until its completion, [since] the fraud on the court would not be fully effected until $80 \%$ of the impounded funds were distributed. .." Id. at 419. The statute under which petitioners were charged gave the court power to punish misbehavior of "any person in its presence," see 18 U.S.C. \$\$ 401-03 (1958). The convictions were reversed on the ground that the misbehavior in the presence of the court had occurred more than three years prior to the filing of the information, and the statute had then begun to run irrespective of any acts in pursuance of the scheme within the indictment period. "[T] he difficulty with [the government's] theory lies in the nature of the offense described by" the statute. 317 U.S. at 419. Only Justice Jackson dissented, emphasizing the "object" of the defendants. 317 U.S. at 442.

In United States v. Irvine, 98 U.S. 450 (1878), an act of Congress provided a penalty for ". . any . . . attorney . . . who shall wrongfully withhold from a pensioner" certain funds allowed disabled war veterans and widows. Act of July 4, 1864, 13 Stat. 389 (1864). The defendant wrongfully withheld the complainant's pension in 1870 and was indicted in 1875. The court held the action barred by the applicable two year statute of limitation, refusing to allow that "every year, every month, every day, was a withholding, within the meaning of the statute. We do not so construe the act." 98 U.S. at 452.

48. 544 U.S. 604 (1953).

49. Act of December 28, 1945, ch. 591, 59 Stat. 659 (1945), repealed by Act of June 25,1948 , ch. 646, \& 39, 62 Stat. 992, 1008 (1948).

49a. "The crime [of conspiracy] comes down to us wrapped in vague but unpleasant connotations. It sounds historical undertones of treachery, secret plotting and violence on 
States as "war brides." The couples were later to sever their marital ties. The marriages were performed, and the last spouse obtained entry into the United States as a "war bride" on December 5, 1947.50 Subsequently, the defendants were charged with conspiring to violate provisions making it a crime for an alien to obtain entry by "wilfully false or misleading representation or the wilful concealment of a material fact." into evidence a number of acts performed and statements made by the coconspirators after the last entry had been cleared.52 On certiorari, petitioners protested that the conspiracy, if there had been one, ended on the date of the last entry, and that the acts and declarations made thereafter were erroneously admitted.

Planning to avoid the impact of Krulewitch, the government this time had taken care to lay a foundation in the indictment for the admission of the evidence. The first count alleged that integral to the conspiracy were two subsidiary goals which extended beyond the date of entry: (1) subsequent concealment of the unlawful conspiracy and (2) subsequent separation and divorce. ${ }^{53}$ Moreover, the government did not rely on mere implication to prove

a scale that menaces social stability and the security of the state itself." Krulewitch v. United States, 336 U.S. 440, 448 (1949) (Jackson, J., concurring).

50. 344 U.S. at 616. "By that time all misrepresentations, concealments, and false statements, if any, in furtherance of such entries had occurred." Brief for Petitioners, p. 26.

51. It is noteworthy that actually two sorts of conspiracies had been alleged in Count One, on which the defendants were found guilty. (1) Conspiring under what is now $\S 371$ to commit the substantive offenses of obtaining unlawful entry by false or misleading representation (under Act of March 4, 1929, ch. 690, § 1(a), 45 Stat. 1551 (1929), repealed by Act of June 27, 1952, ch. 477, § 403(a), 66 Stat. 279 (1952) and to make false application to immigration authorities [(now 18 U.S.C. $\$ 1546$ (1958))] and (2) conspiring "to defraud the United States of and concerning its governmental function and right of administering the Immigration and Naturalization Service. . ." Record, p. 4. These two charges are vitally distinct, as shall be observed in the discussion of United States v. Klein, 247 F.2d 908 (2d Cir. 1957). Cf. text at note 124 infra, for the second conspiracy did not focus upon illegal entry. But the Court did not grasp the distinction between the two theories and spoke of the second conspiracy charged as one "to defraud the United States. ... ' by obtaining the illegal entry into this country of three alien spouses. . . " 344 U.S. 604, 605 (emphasis added). The Court thus added words to the indictment which destroyed the distinction, limiting the government's case to essentially one theory; that the defendants conspired to obtain "illegal entry."

52. The testimony objected to consisted largely of evidence to the effect that the parties to each "marriage" lived apart from each other (Record, pp. 65-66, 69, 135-37, 210, 250, 260 ); that the husband in one marriage lived and slept with his former wife of another marriage (Record, pp. 69, 104, 105, 141, 143, 177), and took her to night clubs where they had their pictures taken (Govt. Exhibits Nos. 22, 23, 24, 25 ; Record, pp. 16, 61, 168, 169, $176,178,181-84,280,287)$. Over objection, this evidence was admitted against all petitioners (Record, pp. 67, 68, 140,142) on the basis of indictment's allegation that the defendants "would at all times subsequent to the formation of the said conspiracy conceal such transactions and acts aforesaid and would do such other, further and different acts as they might deem necessary and expedient to prevent the disclosure to the United States Immigration and Naturalization Service of the existence of said conspiracy." (Record, pp. 7, 67, 68).

53. Record, pp. 6-7. 
conspiratorial goals; it was prepared to prove them with "ample direct" 4 testimony of falsified destinations of the spouses on and before December 5 , $1947^{55}$ and a number of acts severing legal ties, including a divorce as late as March $31,1950.56$

Yet no member of the Court was willing to be persuaded that the conspiracy continued beyond the date of the substantive offenses-the date on which unlawful entry had been obtained. ${ }^{57}$ The reason for the government's lack of success on this point is hard to disentangle from among the many threads of the majority's opinion. Essentially, it appears that the Court ignored the most striking distinction between this case and $K$ rulewitch-the government's seemingly well-founded contention that the acts of separation and divorce were not a mere retrospective concealment of a consummated scheme to obtain entry, but an integral part of the plan Lutwak originally devised. ${ }^{68}$ If it had come to grips with this argument, the court would have found itself face to face with the reasoning of Lonabangh $v$. United States ;" but the Court merely recited the Krulewitch admonition against holding that "in every conspiracy there is implicit an agreement as a part thereof for the conspirators to collaborate to conceal the conspiracy." 60 Finding "no statement in the indictment

54. Cf. Brief for the United States in Opposition to Certiorari, p. 20.

55. E.g., when one of the "brides" entered New York, she represented that she was going to live with her "husband" in Chicago, giving his address-but immediately went off to live elsewhere. (Record, pp. 62-63, 65-69). The falsified destinations were viewed by the government as "clear and direct evidence in public records that continuing concealment after entry into the United States was a part of the conspiracy." Brief for the United States in Opposition to Certiorari, pp. 20-21.

56. Record, pp. 91-92, 69-70.

57. 344 U.S. at 617. Justices Jackson, Black and Frankfurter, dissenting, agreed with the majority on this point. Id. at 622 .

58. One of the war veterans-an ex-Wave-who was sent to Europe testified that at the very inception of the scheme, in late 1947, one of the petitioners twice asked her whether she "knew of any girls who would go to Europe and marry her brother and bring him here to the States," the girl to have her way paid and to receive a fee and "at the end of the period of six months, they could be divorced, and they would not have to consummate the wedding." Record, pp. 29-31, 37-38. And see note 56 supra. One divorce did take place as late as March 31, 1950. The government had stressed this second theory by which the conspiracy was deemed to continue far more strongly than the conspiracy to conceal. See Brief for the United States in Opposition to Certiorari, pp. 19-22, and the absolutely unequivocal presentation in the Brief for the United States, p. 47, Lutwak v. United States, 344 U.S. 604 (1953). Id. at 45.

It was presumably as important to Bess Osborne, for example, that she be freed of even formal legal ties to Munio Knoll, who meant nothing to her, as it was that she be paid the $\$ 1,000$ which was actually paid to her as promised, after Munio Knoll's entry into the United States as her spouse .... . It was equally vital, as the conspirators had made clear from the beginning, that Munio and Maria be re-united after entering the United States. The separations and divorces were thus no less essential to the successful conclusion of the conspiracy than the fraudulent representations by means of which the entries were accomplished.

59. 179 Fed. 476 (8th Cir. 1910). See also notes $46-47$ supra and accompanying text.

60. 344 U.S. at 616 . 
of a single overt act of concealment that was committed after December 5, 1947, and no substantial evidence of any," the Court reasoned that the conspirators never agreed to conceal the conspiracy. ${ }^{61}$ Not only did this emphasis on concealment surprisingly disregard the government's main contention, but even with respect to the allegations of concealment, this conclusion seems so much less than compelling, both as to matters of fact and of law, that it is tempting to suggest the decision was prompted by a reluctance to breathe life into the intimations of Krulewitch. ${ }^{62}$ The fact that the Court ultimately took recourse to the harmless error rule in order to sustain the convictions does not detract from this inference. ${ }^{63}$

When in Grunezwald v. United States ${ }^{64}$ the Supreme Court was faced again with the allegation of an ancillary plan to conceal, it was the supposed agreement's effect upon the statute of limitations, not the admissibility of evidence, which was at issue. While the Court had refused to rule out the possibility that concealment could prolong a conspiracy for purposes of admitting evidence, it did not follow that concealment would allow the conspiracy to be extended for statute of limitations purposes as well. No longer was the question what

61. Ibid. (emphasis added).

62. Attaching significance to the fact that not one overt act after December 5 was pleaded in the indictment seems wholly misplaced. Modified only by general rules of sufficiency of indictments, only one overt act need be pleaded in furtherance of a conspiracy and proof of others at trial is not barred. United States v. Negro, 164 F.2d 168, 173 (2d Cir. 1947). Moreover, even had the court been warranted in passing off the record as presenting no "substantial" evidence of concealment after December 5 , it is strange to argue that therefore the conspirators had not agreed to conceal the conspiracy. This is like saying that because there is no evidence of conspirators having robbed a bank, they did not agree (conspire) to do so. As a matter of the record, there were substantially uncontroverted misrepresentations of destinations and plans. See, e.g., Record, pp. 62-63 and note 85 infra. Compare Justice Minton's statement in the opinion that the petitioners' belief that they were violating Congress' intent 'is evidenced by their care in concealing from the immigration authorities that the ostensible husbands and wives were to separate immediately. ..." 344 U.S. at 611.

63. 344 U.S. at 619-20. Fed. R. CRTMr. P. 54(a) provides "Harmiess ERror. Any error, defect, irregularity or variation which does not affect substantial rights shall be disregarded." The court had to dispose of only one of the assigned errors in this manner, a hearsay declaration, because it ruled the testimony as to the disputed acts admissible notwithstanding that the conspiracy had terminated. This position had been urged quite strongly in the Brief for the United States, pp. 33-42, with virtually no authority other than United States v. Rubenstein, 151 F.2d 915 (2d Cir. 1945), cert. denied, 326 U.S. 766 (1945).

The court never determined whether the marriages had been valid. The majority passed the question off as "immaterial," labelled the marriages as "fake" and sustained the convictions on the ground that the defendants had conspired to violate the intent of Congress, which was not "to provide aliens with an easy means of circumventing the quota system by fake marriages." 344 U.S. at 611 . Without remanding for a finding on the lawfulness of the marriages as a matter of French law and conflict of laws, the Court turned to "the common understanding of marriage, which Congress must have had in mind. . " Ibid. Compare quotation from Justice Holmes in note 3 supra.

Justice Jackson, joined by Justices Black and Frankfurter, strongly dissented.

64. 353 U.S. 391 (1957). See Note, 56 ColUM. L. REv. 1216 (1956). 
sort of evidence should have been admitted against the defendants at trial. It was rather, should the defendants have had to stand trial at all. This difference would have given the Court in Grunewald a fairly rational way to distinguish prior cases, and to declare that insofar as ancillary concealment might lead to "an indeterminate extension of the statute of limitations,"65 it would not be tolerated as a matter of law. Had one, in fact, been able to read the opinion the Court was preparing to hand down twenty-one days later, in Yates $v$. United States, ${ }^{, 6}$ he might well have conjectured just such a disposition. Yates and others who had founded the Communist Party of the United States in $1945^{67}$ were indicted in 1951 for conspiring to "organize" a society which advocated violent overthrow of the government. ${ }^{68}$ The petitioners claimed the convictions should have been barred by the three-year period of limitation. ${ }^{60}$ The government alleged that petitioners had engaged in continuous organizational activities within three years of the indictment. The Court responded by allocating nine pages of the United States Reports ${ }^{70}$ to an analysis of "organize," ultimately agreeing that "the word refers only to acts entering into the creation of a new organization, and not to acts thereafter performed, even though such acts may loosely be termed 'organizational.' "'11 The Court's reasoning in the Yates case was that left so inexplicably wanting in Jackson's concurrence in Krulewitch ;2 "We think," said the Court in Yates, ". . . that petitioners' position must prevail, upon principles stated by Chief Justice Marshall more than a century ago:

The rule that penal laws are to be construed strictly, is perhaps not much less old than construction itself. It is founded on the tenderness of the law for the rights of individuals; and on the plain principle that the power of punishment is vested in the legislative, not in the judicial department. It is the legislature, not the Court, which is to define a crime, and ordain its punishment. ${ }^{73}$

65. Krulewitch v. United States, 336 U.S. 440, 456 (1949) (Jackson, J., concurring).

66. 354 U.S. 298 (1957). The case was heard by the Court six months before Grumewald.

67. Id. at 304 n.5.

It is not disputed that the Communist Party, as referred to in the indictment, came into being no later than July 1945, when the Communist Political Association was disbanded and reconstituted as the Communist Party of the United States. The original party was founded in this country in 1919.

68. 18 U.S.C. $\S 2385$ (1958) :

Whoever organizes or helps to organize any society, group, or assembly of persons who teach, advocate, or encourage the overthrow or destruction of any [government in the United States] by force or violence, ...

69. The three year statute was still in force for purposes of this prosecution. 354 U.S. at 304.

70. Id. at 303-12.

71. Id. at 310 .

72. See notes $37-47$ supra and accompanying text.

73. 354 U.S. at 304 , quoting from United States v. Wiltberger, 18 U.S. (5 Wheat.) 76,95 (1820). 
But the Court in Grunewald was still at pains neither to affirm nor to disavow the proposition that planned concealment might extend the time scope of conspiracy.

Grunewald arose after two New York business firms, discovering that they were under investigation by the Treasury Department for tax evasion, sought to "fix" the pending cases by recourse to certain individuals, among whom were numbered Treasury officials and men with influence in Washington. The alleged conspirators succeeded in having "no prosecution" rulings "4 handed down for the two firms in 1948 and 1949.75 About five years later, on October 25, 1954, a Brooklyn Grand Jury returned an indictment against the defendants charging a violation of the general conspiracy statute. ${ }^{76}$ Laboring under the erroneous impression that a three-year statute of limitations was applicable to the offense charged, ${ }^{77}$ the government sought to prove that the conspiracy was still in existence as late as October 25, 1951, despite the last "no prosecution" rulings having been handed down in 1949. To meet this requirement the government was prepared to introduce, as "raw facts," a number of overt acts of concealment within the indictment period, including the following: (1) one of the alleged conspirators had a carpenter build a hiding place for secret papers ${ }^{78}$ (2) another had misled revenue agents as to the nature of the expenses listed on their books ;9 $^{79}$ (3) numerous instructions were passed

74. "A 'no prosecution' ruling is an internal decision by the investigative branch of the Bureau of Internal Revenue not to press criminal charges against a taxpayer." Grunewald v. United States, 353 U.S. 391, 395 n.5 (1957).

75. Id. at 395 .

76. 18 U.S.C. § 371 (1958). The charge was not a conspiracy to commit a substantive offense elsewhere defined in the criminal code, but to "defraud the United States with reference to certain tax matters." 353 U.S. at 393 . The charge had to be so devised because there is no explicit provision in the federal criminal code making it a crime to obtain "no prosecution" rulings. Yet, inasmuch as the alleged object of the conspiracy was conceived to be the achievement of a relatively affirmative and concrete goal, the Court regarded the allegation as it would have a charge of, e.g. conspiracy to rob a bank, rather than conspiracy to defraud by concealing past misconduct as in e.g. United States v. Klein, 247 F.2d 908 (2d Cir. 1957), cert. denied, 355 U.S. 924 (1958) in text at notes 111-32 infra. For the purposes of this analysis, Grunezvald is better treated with Krulewitch than with Klein.

77. On September 1, 1954, the statute of limitations was amended to provide for a five year period of limitations for Title 18 offenses generally. An Act to prohibit payment of annuities to officers and employees of the United States convicted of certain offenses, and for other purposes, 68 Stat. 1145 (1954), 18 U.S.C. $\$ 3282$ (1958). Nonetheless, the case was tried as though the three year statute of limitations was still applicable, an error the Supreme Court drew attention to in footnote, 353 U.S. at 396-97 n.9. Actually, the government's mishandling of this point apparently went even deeper than the Court noticed: the Internal Revenue Code of 1954, Act of August 16, 1954, ch. 736, \& 6531, 68A Stat. 3, provided that a six year statute of limitations should apply "(8) for offenses arising under section 371 of Title 18 of the United States Code, where the object of the conspiracy is to attempt in any manner to evade or defeat any tax or the payment thereof." And cf. Braverman v. United States, 317 U.S. 49, 55 (1942).

78. Record, pp. 543-45.

79. Record, p. 361. 
among those involved not to tell the grand jury anything $;^{80}$ and (4) one conspirator warned a secretary to tell any inquirer that she "didn't remember." The last of these acts had been performed as late as May of 1952.82 On these acts the government, while it may have overlooked the best possible strategy, ${ }^{83}$ managed to erect a number of theories by which to save the indictment. One was that the acts of concealment were an integral part of the conspiracy to obtain fixes and were designed to protect the conspirators from discovery. ${ }^{84}$ Another was that the acts of concealment were part of a conspiracy to keep a tax-fixing "ring" in business indefinitely. ${ }^{85} \mathrm{~A}$ third was that the aim of the conspirators was not merely to gain departmental "no prosecution" rulings

80. Record, pp. 171, 180, 813-14.

81. Record, pp. 531-34.

82. Record, p. 531.

83. United States Attorney J. Edward (now Chief Judge) Lumbard, who framed the indictment, seems to have laid the groundwork for a more inspired theory of the case than ever reached the ears of the Supreme Court. In Haas v. Henkel, 216 U.S. 462 (1910) the Court had held that conspiracy to defraud was broad enough in its reach to convict a Department of Agriculture employee and others who had conspired to falsify cotton crop reports.

[A]ny conspiracy calculated to impair ... [the Department of Agriculture's] efficiency and destroy the value of its operations ... as fair, impartial, and reasonably accurate, would be to defraud the United States. . .

Id. at 479-80. And in the landmark case of Hammerschmidt v. United States, 265 U.S. 182 (1924), Chief Justice Taft in "defining" the crime said:

it ... means to interfere with or obstruct one of [the United States'] lawful governmental functions by deceit, craft or trickery, or at least by means that are dishonest. It is not necessary that the government shall be subjected to property or pecuniary loss by the fraud, but only that its legitimate official action and purpose shall be defeated by misrepresentation, chicane or the overreaching of those charged with carrying out the governmental intentions.

Id. at 188. The wording of the indictment in Grunewald strongly indicates that the acts of concealment may have been to take on the color, not of the cover-up of an otherwise consummated offense, but of the substance of a conspiracy to defraud the United States on both or either of two theories (1) by impairing it in its lawful governmental function of detecting and prosecuting tax violators by means which were, at least "dishonest" (itself construable as an unlawful conspiracy under Hammerschimdt) and (2) depriving it of the faithful services and actions of its employees (itself an unlawful conspiracy under Haas v. Henkel). Cf. the Indictment at Record, p. 4.

The otherwise very fine government briefs, rather than contend that the concealment was itself the unlawful conspiracy, artlessly argued that a conspiracy "can in fact embrace a specific agreement to conceal the conspiracy." Brief for the United States, p. 54. (Emphasis added.) Krulewitch and Lutwak might have been refought with valor, but discretion dictated they be avoided. Somewhere in the course of litigation and appeal, what must have been intended to be a unit, one single unlawful conspiracy, continuing well into the indictment period, had been disjointed and reduced to a variation upon the main aim-subsidiary aim dichotomy. But see the discussion of United States v. Klein, 247 F.2d 908 (2d Cir. 1957), cert. denied, 255 U.S. 924 (1957), at notes 111-32 infra and accompanying text.

84. 353 U.S. at 399-406; see notes 87-95 infra.

85. Id. at $406-07 \mathrm{n} .20$; see note 96 infra. 
but to maintain these rulings in effect until 1952, for the protection of the taxpayers..$^{86}$

The government did not consider the first theory-that the concealment was directed towards protecting the conspirators-as barred by its failures in Krulewitch and Lutwak: "[B]oth opinions recognize that agreements to conceal can factually be parts of conspiracies to commit other crimes."87 Here, a jury had found the facts. The Court reacted by, on the one hand, finding the government's theory too much like that rejected in Krulezeritch and Lutwak to be palatable. ${ }^{88}$ On the other hand, it refused to rule that an agreement to conceal cannot, as a matter of law, stay the running of the statute of limitations. As a result, the Court's only recourse was to refuse to accept the jury findings ${ }^{88}$ despite the various acts of concealment ${ }^{90}$ and testimony that as far back as March, 1949 the conspirators were searching for money to conceal the fixes. ${ }^{01}$ In so doing, Mr. Justice Harlan complained that "there is not a shred of direct evidence in this record to show anything like an express original agreement among the conspirators to act in concert in order to cover up, for their own self-protection, traces of the crime."92 Even so, no more "direct evidence" of "express original agreements" appears to have been demanded to infer conspiratorial agreements for non-concealment objectives. ${ }^{93}$ The agree-

86. Id. at 406-15; see text at notes 97-104 infra.

87. Brief for the United States, pp. 55-56, United States v. Grunewald, 353 U.S. 391 (1957).

88. 353 U.S. at 399.

We think that the government's first theory-that an agreement to conceal a conspiracy can, on facts such as this, be deemed part of the conspiracy and can extend its duration for the purposes of the statute of limitations-has already been rejected by this Court in Krulewitch ... and Lutwak. ...

89. Id. at 406.

90. See notes 78-82 supra and accompanying text.

91. Record, pp. 127-29.

92. 353 U.S. 391, 404. In analyzing both the Krulewritch and Lutwak decisions, the government argued, quite justly, that neither decision had denied that an agreement to conceal could be proved "and found by the jury under proper instructions." Brief for the United States, p. 58, Grunewald v. United States, 353 U.S. 391 (1957). The manner in which the Court disposed of the contention could be read only as inviting further attempts to prove such an agreement in the future.

A reading of the record before us reveals that on the facts of this case the distinction between "actual" and "implied" conspiracies to conceal ... is no more than a verbal tour de force. ... When we look to the facts of the present case from which the government asks us to deduce an "actual" agreement to conceal reveals nothing beyond that determined in prior cases.

353 U.S. at 402.

93. The tenor of American decisions even today is still affected by a charge to the jury at Nisi Prius (per Coleridge J., in Regina v. Murphy, 8 C. \& P. 297, 310 (1837) which Greenleaf incorporated in his First Edition:

Though the common design is the essence of the charge, it is not necessary to prove that the defendants came together and actually agreed, in terms, to have that design, and to pursue it by common means. If it is proved that the defendants pursued by 
ment to "fix" was largely implied from the fact that no-prosecution rulings were issued by the internal revenue service and from direct evidence revealing the steps taken to obtain them; in like manner the government wished to infer an agreement to conceal primarily from the concerted acts of concealment. But inasmuch as covering up a wrongdoing has been "a concomitant, certainly, of every crime since Cain attempted to conceal the murder of Abel from the Lord,"94 it appeared the Justices were going to demand a relatively imposing quantum of evidence that the concealment was pursuant to "an express original agreement," before allowing such acts to extend the duration of the conspiracy. ${ }^{95}$

After summarily disposing of the theory that there was a continuous tax fixing "ring,"98 the Court turned to the theory that the concealment was pursuant to an agreement to protect the taxpayers, not the conspirators themselves. The government's argument here was grounded on the fact that tax evasion

their acts the same object, often by the same means, one performing one part and another another part of the same, so as to complete it, with a view to the same object, the jury will be justified in the conclusion, that they were engaged in a conspiracy to effect that object.

3 GReenleaf, Evidence $\S 93$ (1st ed. 1853). See, e.g., Duke v. United States, 233 F.2d 897, 900-01 (5th Cir. 1956) ; Badon v. United States, 269 F.2d 75, 78 (5th Cir. 1959), cert. denied, 361 U.S. 894 (1959). See generally Cousens, Agreement as an Element in Conspiracy, 23 VA. L. REV. 898 (1937).

94. 353 U.S. at 406.

95. Or, perhaps more realistically, the Court was saying in its own way that it would refuse to entertain such a theory in the future regardless of the quantum of proof offered. See Foreman v. United States, 259 F.2d 128, 133-35 (9th Cir. 1958), modified, 261 F.2d 181 (9th Cir. 1958), aff'd, 361 U.S. 416 (1960).

96. 353 U.S. at $406-07$ n.20.

The government had contended in its brief that the concealment was designed to allow the continued operation of a "ring," the "general machinery [of which] was established and ready to operate whenever there could be found a taxpayer willing to pay enough for the 'services.' " Brief for the United States, p. 48, Grunewald v. United States, 353 U.S. 291 (1957). The government abandoned this theory on oral argument, 353 U.S. at 406-07 n.20, but the manner in which the Supreme Court dismissed it leaves room for concern.

The trouble is not only that the theory was never submitted to the jury, but that no overt act done to further the purpose of engaging in "new" business was charged or proved to have occurred after October 25, 1951. If one of the purposes of the conspiracy was to engage in the business of fixing tax cases generally, it must be deemed to have been abandoned in $1951 \ldots$ since there is no indication that there was an intent to resume operations.

Ibid. (emphasis added). To what sort of conduct do "fixing tax cases generally" and "operations" refer? How does one deny such a charge? Whose tax return investigations would a defendant be charged with conspiring to fix? How? When? The behavior alleged might be as ill defined as concealment itself and, if ever elevated to the status of a crime, such a conception of conspiracy could give the state more power to do less justice than at any time since it was criminal "to compass or imagine the death of the King. ..." 25 Edw. 3 (1351); see the charge to the jury by Eyre, L.C.J., in 1 Sibly, The Genutne Trial of Thomas Hardy for High Treason 12 (2d ed. 1795). 
cases were governed by a six-year statute of limitations, ${ }^{97}$ which began to run in 1946 when the last returns were filed by the taxpayers; this meant that final immunity from prosecution could not have been obtained until $1952 .{ }^{98}$ The government built upon this to argue that the same overt acts which the Court refused to construe as in furtherance of a conspiracy to protect the conspirators, be allowed to support the inference of a scheme to protect the taxpayers until 1952 as part of the quid pro quo of the original agreement.99 The Court's readiness to agree that this theory was "unexceptionable"100 seems to reflect an attitude that acts of criminals to cover up their own crimes are apt to arise spontaneously after the crime; but that when they go to the trouble to conceal for the benefit of others, the explanation is more likely an express agreement entered into before the consummation of the substantive offense. Whatever the logical merits of this Cain-Abel, vendor-vendee distinction, it invites an analysis of the facts which is challenging to undertake in practice where there is no direct evidence of what the conspirators actually did bargain for: $:^{101}$ since any steps the conspirators may have taken to protect the taxpayers would have had the effect of protecting themselves as well, the acts of concealment might as readily have been motivated by one desire as by the other. Nonetheless, the Court accepted the government's third theory and remanded the case for a finding on this largely speculative issue. ${ }^{102}$

In its readiness to accept the government's final theory, the Court in Grunewald may well have been influenced by the fact that six years after the filing of the allegedly false returns, the statute of limitations would run on criminal prosecutions arising therefrom. ${ }^{103}$ Any act of concealment occurring after that time could not be construed as in furtherance of a conspiracy to maintain the

97. 26 U.S.C. § 3748 (1940). Cf. 26 U.S.C. § 6531 (1958).

98. 353 U.S. at 395 n.5. A "no prosecution" ruling is but an internal decision by the investigative branch of the Bureau of Internal Revenue not to press criminal charges against a taxpayer, i.e., it might have been rescinded as long as the statute on the underlying offense had not run.

Compare United States v. Kissel, 218 U.S. 601, 607 (1910) ("a vote upon pledged stock that might be redeemed was not necessarily lasting, and further action might be necessary to reach the desired result.").

99. 353 U.S. at 408.

If the central objective of the conspiracy was to protect the taxpayers from taxevasion prosecutions, on which the statute of limitations did not run until 1952, and if in 1948 and 1949 "no prosecution" rulings were but an "installment" of what the conspirators aimed to accomplish, then it is clear that the statute of limitations on the conspiracy did not begin to run until 1952, within three years of the indictment.

100. 353 U.S. at 408.

101. The best the Court could venture was that "there is little indication that it was the specific and narrow end of obtaining 'no prosecution' rulings which was to be the quid pro quo." 353 U.S. at 409 n.23.

102. A first retrial resulted in a hung jury, and a second in final acquittal. N.Y. Times, April 18, 1959, p. 16, col. 2.

103. See note 99 supra. 
no-prosecution rulings. ${ }^{104}$ Thus, the Court could accept this theory without sanctioning an eternally indictable conspiracy to conceal a conspiracy. But with only the slightest variation in the government's case, such an eternally indictable conspiracy may in fact be constructed, as demonstrated by Forman v. United States. ${ }^{105}$ There, shortly after Grunewald was handed down, the government sought to prolong the duration of an alleged tax evasion conspiracy by arguing that acts of concealment within the indictment period were in furtherance of a scheme to prevent the government from collecting the back taxes. "Tax evasion," the ninth circuit remarked, "may include attempts not only to block prosecution of the taxpayers [as in Grunewald] but to block collection of the tax."106 The critical difference between these two theories is that there is no statute of limitations for the collection of tax in the case of a false or fraudulent return, ${ }^{107}$ and thus, under this variation of Grunewald, the conspiracy might continue indefinitely, and not for six years only. When the Supreme Court decided the Forman case, they seemed to have missed the significance of this distinction, saying that "the concealment of the 'holdout' income must continue if the evasion is to succeed. It must continue until action thereon is barred and the evasion permanently effected."108 If the Court had realized that an action for the collection of back taxes can never be barred, would it have reached the same result? Would the Court have deemed the final theory of Grunewald "unexceptionable" if it had realized that it was "opening the floodgates against which Krulewitch warned."109

\section{Conspiracy to Defraud: The Problem Reformulated}

After Krulewitch, Lutwak and Grunewald, it had become clear that at least one doctrinal roadblock facing the government was the court's unarticulated doubt as to whether every act embraced in a conspiratorial agreement can be

104. Such acts would have assumed the aspect of the very cover-up of a past offense which the Court had refused to sanction as extending the conspiracy under the first theory.

105. 259 F.2d 128 (9th Cir. 1958) ; order modified, 261 F.2d 181 (9th Cir. 1958) ; aff'd on rehearing, 264 F.2d 955 (9th Cir. 1959), aff'd, 361 U.S. 416 (1960). The allegations in this case arose out of allegedly fraudulent income tax returns filed in the years 1943 through 1946. 361 U.S. at 420 . To save the indictment, it was alleged that within the period of limitations there was a conspiracy charged under $\S 371$ to violate 18 U.S.C. $\S 1001$ (within jurisdiction of any agency of the United States, knowingly to conceal a material fact or make fraudulent statements) and also to violate INT. REv. CoDE of 1939 \$ 145 (b) [now INr. Rev. CoDE of $1954, \S 7201]$ which punishes ". . . any person who wilfully attempts in any manner to evade or defeat any tax imposed by this chapter. .."

Defendants were convicted on the theory that there was a subsidiary conspiracy to conceal the conspiracy to file false returns; but at 259 F.2d 128, the Court of Appeals, analyzing the then recent Grunewald decisions, directed that judgment be entered for appellants. Then in a rehearing, 261 F.2d 183, the government won a new trial on the theory discussed in text.

106. 261 F.2d at 183 (emphasis added).

107. INr. Rev. Code of 1939, § 276(a) [now 26 U.S.C. § 6501 (c) (1) (1958)].

108. 361 U.S. at 424 (emphasis added).

109. Grunewald v. United States, 353 U.S. 391, 405 (1957). 
"in furtherance of" the conspiracy in the sense of the statute. A statute directed at a substantive offense would seem concerned, as was pointed out in the Lonabaugh case, ${ }^{110}$ only with the commission of that offense, and subsequent acts of principals to the crime would seem outside the scope of the statute's interdiction. If this problem of statutory construction were the source of the Court's reluctance, only a statute construed to make a crime out of the very agreement to conceal itself would leave no question that every overt act of concealment "in furtherance of" the conspiratorial agreement would be an overt act in furtherance of the crime. This was the conception which underlay the government's success in United States $v$. Klein. ${ }^{111}$

On September 17, 1954, Klein and his codefendants were indicted upon charges of tax evasion in connection with the sales of Canadian whiskey. Though transported directly from Canada to the United States, the whiskey took a more circuitous path on paper, passing through the books of no less than seventeen foreign corporations in such manner as to cast doubts upon the legality of the defendants' 1948 tax returns. ${ }^{112}$ A six-year statute of limitations being applicable to income tax offenses under the Internal Revenue Code, ${ }^{113}$ the timeliness of the indictment was unquestioned as to four counts arising thereunder; but at the close of the government's case these charges were dismissed, ${ }^{114}$ and there remained only a count charging conspiracy to defraud the United States. This count, the fifth, "was not a charge of wilfully attempting to evade taxes, but of unlawfully conspiring to obstruct the Treasury Department in the exercise of an essential function, the collection of the revenue."116 The government claimed this allegation should stand notwithstanding dismissal of the four counts charging the defendants with having evaded or having even conspired "to evade or defeat" income taxes due or owing. ${ }^{110}$ One of the Treasury Department's functions being to ascertain what revenue, "if any" was owing, and the conspirators by their acts of concealment having impeded such a determination, it was argued that they might be guilty of a conspiracy to defraud even if they had not in fact evaded the payment of any taxes. ${ }^{117}$ Believing that the period of limitations applicable to this conspiracy charge was three years, the government had to prove that the conspiracy alleged had not terminated prior to Sept. 17, 1951 to sustain this count. ${ }^{118}$ Ten acts committed after this date were offered in proof of the con-

110. Lonabaugh v. United States, 179 Fed. 476 (8th Cir. 1910) at notes $40-46$ supra and accompanying text.

111. 247 F.2d 908 (2d Cir. 1957), cert. denied, 355 U.S. 924 (1957).

112. 247 F.2d at 912.

113. INT. REv. CODE of 1939, § 3748(a), 53 Stat. 461.

114. 247 F.2d at 910.

115. Brief for the United States in Opposition to Certiorari, p. 21, United States v. Klein, supra note 111.

116. Indictment of September 17, 1954, Record, p. 137, United States v. Klein, 247 F.2d 908 (1957).

117. Id. at $18-20$.

118. On this theory the case was argued. But at the time of the finding of the first indictment, May 13, 1954, a six year statute could have been pleaded under 26 U.S.C. $\$ 3748$ 
tinuation of an agreement to conceal the "nature and source"110 of the income reported in the 1948 returns. They ranged from a fairly cryptic phone call ${ }^{120}$ to a number of allegedly false statements to Treasury officials, an instance in 1952 of Klein's "clinging to his earlier position," an "evasive affidavit," and Klein's "implication to the Treasury. . . .121 Taken singly, there was nothing criminal in the evasions, implications, false statements and position clinging. ${ }^{122}$ But in sum, under the government's theory, they took the shape of an unlawful conspiracy to defraud the United States. In the disarmingly frank phrase of the trial judge, the defendants had been guilty of conspiring "to throw sand in the government's eyes."123 By characterizing the conspiracy as one in which concealment itself was the unlawful goal, the acts of concealment could not be dismissed as an effort merely "to hide the past, as in Grunewald . . ."124 but proved the continuing vitality of the very crime alleged. What seems intriguing is that the acceptance of this new approach made convictions possible despite the government's inability to prove that any supposed object of the concealment was a crime. ${ }^{125}$ The verdicts were affirmed by the Second Circuit, ${ }^{126}$ and the Supreme Court denied certiorari. ${ }^{127}$

(1939). See Braverman v. United States, 317 U.S. 49 (1942); a superseding indictment, under which the defendants were convicted, was found on September 17, 1954, after the statutory changes cited at note 77 supra. Since the court took this latter date as the critical one for determining the timeliness of the indictment, 247 F.2d at 912, presumably the government could have pleaded either a five year statute under 18 U.S.C. $§ 3282$ (1958) or a six year statute under 26 U.S.C. $\$ 6253$ (1958).

119. Superseding indictment, September 17, 1954. Record, vol. 1, pp. 137-38, United States v. Klein, 247 F.2d 908 (2d Cir. 1957).

120. 247 F.2d at 915 :

Klein said: "Yes, you can use your check. Get a good tax man."

[Defendant] Alprin asked, "What do you mean?"

The reply: "I can't talk on the telephone. Rosenberg will be in to see you on Mon-

day. Don't do anything until Monday, when Mr. Rosenberg will come to see you."

121. 247 F.2d at 915 .

122. The false statements here alluded to were not made under oath.

123. United States v. Klein, 139 F. Supp. 135, 141 (S.D.N.Y. 1955).

124. 247 F.2d at 918.

125. Compare Lutwak v. United States, 344 U.S. 604 (1953), at note 63 supra; there the majority upheld the conspiracy convictions by passing off the marriages as "sham," without determining their validity as a matter of law. But cf. the later opinion of Judge Clark, concurring in United States v. Bufalino, 285 F.2d 408 (2d Cir. 1960) (conspiracy to obstruct justice and to commit perjury by giving false and evasive testimony) :

True, there might arise circumstances where a defendant's concealment would raise questions of propriety, as where he was concealing an actual crime. But under the circumstances here present, where no crime is indicated, some proof of illegality [as opposed to crime?-Ed.] in the actions concealed would seem an essential to any Id. at 420 . conviction on either a substantive or a conspiracy count.

But see United States v. Perlstein, 126 F.2d 789, 795 (3d Cir. 1942), cert. denicd, 316 U.S. 678 (1942).

126. 247 F.2d 908 (2d Cir. 1957).

127. 355 U.S. 924 (1958). 
In the Klein case, the Second Circuit had said that "mere failure to disclose income would not be sufficient to show the crime charged of defrauding the United States . . . "128 But the court, having said what was not sufficient to sustain the charge, retreated to the nebulous and broad dictum of Hammerschmidt v. United States that conspiracy to defraud consists of obstruction of a lawful governmental function "by deceit, craft or trickery, or at least by means that are dishonest."128 The meaning of this critical phrase was dismissed with an abrupt assurance that "the evidence recounted . . . appears directly in line with the crime there outlined."130 If the standards of criminal conduct are to be no more sharply defined than in the epithetical terms of "craft," "deceit," "trickery" and "dishonesty," then the predicated goals of codifying the criminal law must substantially be defeated. The trial judge had charged the jury that though there was no obligation on taxpayers to volunteer information, there was an obligation "to demean themselves honestly."131

The United States in performing its governmental function of assessing and collecting income taxes, is under our law entitled to the economic facts upon which the proper tax is to be computed. It is the duty of everyone in our country to supply those facts as required by law. ${ }^{132}$

But where is that duty to be found? What is the source of the obligation which the conspirators violated in being "evasive," "making an implication" and "clinging to an earlier position"? Apparently only the maelstrom depths of "conspiracy to defraud" itself.

To be sure, the fact that Congress has made conspiracy to defraud a crime may be taken as an indication of its intent to proscribe by those words certain behavior not elsewhere prohibited in the criminal code. Yet, before concluding that such acts of concealment as were involved in Klein ought to be brought within its interdiction, it is worthwhile to explore the consequences of construing "conspiracy to defraud" so broadly. Whether the duration of a conspiracy is prolonged by an ancillary agreement to conceal, or whether conspiracy to conceal is a separately indictable offense under the conspiracy to defraud statute, the result will effect the administration of federal justice in such fundamental rules as the statute of limitations, admissibility of evidence, and constitutional restrictions on venue. Where these are viewed as "rules merely of technical process, to be grudgingly applied,"133 it will not be sur-

128. 247 F.2d at 916 .

129. 265 U.S. 182,188 (1924), quoted in $247 \mathrm{~F} .2 \mathrm{~d}$ at 916.

130. 247 F.2d at 916 .

131. Record, p. 9250, United States v. Klein, 247 F.2d 908 (2d Cir. 1957).

132. Record, p. 9257.

133. 1 Wharton, Criminal Procedure $\$ 367$ (10th ed. 1918) calls the defense of the statute of limitations "one not merely of technical process, to be grudgingly applied, but of right and wise reason. . ." Wharton's authority for the claim purports to be Lord Plunkett and, remarkably enough, Demosthenes, a passage from whom he not only boldly sets out in the original Greek, but, further testifying to the by-gone glories of the bar, refuses to translate. 
prising to find a cool indifference in the face of a movement to confine their efficacy. Especially is this true when the genius of molding acts of concealment into a separate offense-conspiracy to defraud-is that it effectively undermines these limitations upon prosecution while leaving seemingly inviolate the doctrines which have evolved around them. Yet, these rules deserve some respect as an expression of values which have long been accepted both by courts and legislatures. It remains to be considered whether the current development so offends the policies underlying statute of limitations, venue and hearsay doctrines that it ought firmly and unequivocally to be stayed.

\section{The Impact of Concealment on Criminal Procedure}

\section{Statutes of Limitations}

An evaluation of the intended function of statutes of limitations in federal conspiracy law suffers from a paucity of authoritative declarations concerning their underlying rationale. ${ }^{134}$ This is partly attributable to the fact that the courts have rarely faced questions which compelled an extended dissertation upon the nature and purposes of the statute of limitations. ${ }^{135}$ Courts and legislatures may have assumed that criminal statutes of limitations are a product of the same designs as their civil counterparts. The former, no less than the latter, seem to reflect a desire to "quiet title," and both attempt to minimize the possibility of distortion inherent in reconstructing events long after their occurrence. ${ }^{136}$ There are, however, additional considerations involved in bringing an accused to trial on criminal charges. For example, it seems understandable that society would be more willing to "let things lie" when it is acting solely as arbiter between two of its members than when it is itself an aggrieved party. ${ }^{137}$ Moreover, society tends to designate as criminal the very behavior toward which it is least apt to be dispassionate and forgiving. How the balance was struck between countervailing considerations and why there was departure from the common law (at which there was no limitation upon criminal proceedings), ${ }^{138}$ have not been well charted either in legis-

134. See generally Note, 102 U. PA. L. Rev. 630 (1954) and Model Penal Code § 1.07, comment (Tent. Draft No. 5, 1956). But see notes $135,139 \& 141$ infra.

135. But see Adams v. Woods, 6 U.S. (2 Cranch) 336, 342 (1805) (opinion of Chief Justice Marshall), Bridges v. United States, 346 U.S. 209, 218-20 nn.17 \& 18 (1953), and Pendergast v. United States, 317 U.S. 412 (1942) ("every statute of limitations may, of course, permit a rogue to escape."). Id. at 418.

136. See, e.g., Chase Securities Corp. v. Donaldson, 325 U.S. 304, 314 (1945) ("Statutes of limitation ... are practical and pragmatic devices to spare the courts from litigation of stale claims, and the citizen from being put to his defense after memories have faded, witnesses have died or disappeared, and evidence has been lost") ; Guaranty Trust Co. v. United States, 304 U.S. 126, 132-36 ("... a statute of repose, designed to protect the citizen from stale and vexatious claims. ..." Id. at 136).

137. See Wharton, Criminal Procedure § 367 (10th ed. 1918).

138. 1 Wood, Limmrations $\& 28$ (4th ed. 1916); cf. United States v. Cadarr, 197 U.S. 475,478 (1905). Stephen relates that he himself held a brief for the crown in 1863, charging the defendant with having stolen a leaf from a parish register in 1803. 2 STEPEEN, 
lative history or judicial decisions. ${ }^{139}$ One can glean, however, from an analysis of federal and state statutes of limitations that American jurisdictions tend to afford longer statutory periods, or none at all, to the more seriously punished offenses. ${ }^{140}$ This would seem to indicate that whatever the policies of the statutes of limitations are, they will not be allowed to prevail over society's interests in prosecuting those crimes it considers especially grave. ${ }^{141}$ Beyond this, one must look to reason, rather than authority, to determine the goals which such statutes subserve. Certainly they include: (1) the deepseated desire to spare the innocent from the ordeal and ignominy of prosecution and possibly conviction at a time when the presentation of the facts is inevitably less than full, and perhaps distorted; (2) a realization of the extreme inconvenience and cost of impelling the accumulation of records over extended periods of time; (3) the degree to which the secondary deterrence factor decreases when a prosecution is instituted long after the commission of an offense; (4) the reduced need for institutional reformation of persons whose only provable crime occurred in the distant past; and (5) the diminished public clamor for retribution when an offender is not apprehended until long after the crime. The premises which underlie these beliefs do not easily lend themselves to empirical verification. Arguably they are the very sort of propositions-mixed fact, fallacy, and ethic - which are best decided by the community at large, and better regulated by statute than by judicial decision.

To illustrate the possible conflict between the policies underlying the statute of limitations and the use of acts of concealment to extend the duration of a conspiracy, consider an agreement whereby $A, B$, and $C$ conspire to and do rob a bank in 1962 . Subsequent to the robbery (1) $A$ hides a weapon beneath a rock, (2) $B$ rents a safe-deposit box in which to conceal the loot, and (3)

History of the Criminal Law of ENgland 2 (1893). Fortunately, the grand jury threw this particular indictment out.

139. For example, when, in 1954, the general federal statute of limitations was raised from three to five years, 65 Stat. 1154 (1954), amending 18 U.S.C. § 3284, there was no congressional debate on the measure; rather, it passed through Congress as an obscure rider to a bill to prevent payment of annuities to federal employees convicted under various anti-communist statutes. The bill was reported out by the Committee on Post Office and Civil Service, rather than by one of the committees on the judiciary, and neither the House nor Senate report mentioned its significance. H.R. REp. No. 2488, 83d Cong., 2d Sess. (1954), S. Rep. No. 2231, 83d Cong., 2d Sess. (1954).

See also the threadbare discussion with which the Forty-Fourth Congress ushered in a change in the law. 4 Cong. REc. 2275 (1876).

But see H.R. Rep. No. 365, 67th Cong., 1st Sess. 1 (1921) ; H.R. Rep. No. 16, 70th Cong., 1st Sess. 1 (1927) ; S. ReP. No. 1544, 77th Cong., 2d Sess. 1, 2 (1942) ; cf. 1951 U.S. Code Cong. Serv. 1547-48 (letter of Sec'y of State Dean Acheson).

140. A chart appears in Note, 102 U. PA. L. Rev. 630, 652-53 (1954); see also 18 U.S.C. $\S 3281$ (1958) (no period of limitations for capital offenses).

141. But when Parliament passed the first criminal statute of limitations in AngloAmerican law, the consideration which purportedly moved that house was the serious nature of the sanctions which treason convictions imposed. See the Treason Act, 1695, 7 Will. 3 , ch. 3 (repealed $8 \& 9$ Geo. 6, c. 44, § 2, sch.). 
$A, B$, and $C$ agree that if they are asked by anyone, including federal grand juries, about their behavior on the day of the offense, they will endeavor to frustrate the inquiry by evasion, silence, or lies. As long as the status of agreements to conceal remains judicially unresolved, the government may be able to prosecute the conspirators upon either of the two theories previously described in the text even after the statutory period for the underlying substantive offense has expired. ${ }^{142}$

Suppose for a moment that the three arrested for $A, B$ and $C$ 's crime are innocent. With each intervening year, the chances have increased that a witness who might have been able to exculpate them will be unavailable at trial. Similarly, if on the date of the offense all three of them were, for example, at a hotel in a distant city, it may be that six years having passed, the hotel has discarded the records which would substantiate this alibi. And of course memory distorted by time may lead prosecution witnesses erroneously to place the defendants at the scene of the crime. ${ }^{143}$ The effectiveness of the prosecution's

142. The Government may follow any of the following courses:

1. bring an indictment before 1967 for the robbery itself under 18 U.S.C. $\$ 2113$ which carries a maximum of 25 years and $\$ 10,000$. Typically, however, the substantive offense will be more difficult to prove than a conspiracy;

2. bring an indictment before 1967 for conspiracy to commit armed robbery under 18 U.S.C. $\$ \S 371,2113$, the maximum penalty for which is five years and $\$ 10,000$. The indictment being found within five years of the robbery, it will not be necessary for the government to fall back upon acts of concealment to prove the timeliness of the prosecution;

3. bring an indictment before 1967 charging the defendants under both the substantive and conspiracy counts, which would enable the court to impose an aggregate penalty of 30 years and $\$ 20,000$;

4. bring an indictment after 1967

(i) claiming conspiracy to commit armed robbery (18 U.S.C. $\S \S 371,2113$ ), urging acts of concealment as integral to the conspiracy, and proving some such acts within the indictable period. Defendants would thus be confronted with a maximum of five years and $\$ 10,000$, while the prosecution would apparently have to adduce more convincing proof of an "express original agreement" to conceal than it was able to do in Krulewitch, Lutwak and Grunewald; or

(ii) claiming that acts of concealment within the indictable period were pursuant to a conspiracy to defraud the United States under 18 U.S.C. $\& 371$ by obstructing the government in discovery of whether the defendants had robbed a bank. Defendants would still be faced with a maximum of five years and $\$ 10,000$ but the proof adduced could be of a more equivocal nature, at least if $K$ lein be an accurate guide. With respect to maximum penalties, a successful indictment would be indistinguishable under the Lutwak (4-i) and Klein (4-ii) approaches, except in cases covered by special statute.

Thus, in 1968-more than five years after the date of the supposed bank robbery-prosecutions for offenses arising therefrom may remain possible under two of the five modes of procedure, 4(i) and 4(ii). The two alternatives, 1 and 3 , which would have threatened the conspirators with the most serious penalties, would have been barred as of 1967 . While 2 also would be barred in theory, alternative $4-i$, which remains, offers the same sanctions and presents substantially similar problems for the defense.

143. United States v. McWilliams, 69 F. Supp. 812 (D.D.C. 1946), aff'd, 163 F.2d 695 (D.C. Cir. 1947) :

As in all long delayed cases, the witnesses now are scattered; some are not accessible, 
case will likewise diminish with the passage of time, thus making it easier for a guilty man to escape conviction. The net effect will therefore be to minimize "precision"-the ratio of convictions of the guilty and acquittals of the innocent-in those criminal trials conducted after the passage of a substantial period of time. ${ }^{144}$

Even if $A, B$ and $C$ are the ones who have been apprehended, it is questionable whether the policy of bringing them to trial after six years is a wise one. To the extent that the aim of criminal law is to isolate those whose actions indicate that they pose a threat to society, the commitment of $A, B$ and $C$ may no longer be justified; if, delving into their behavior over the past five years or more, the government is able to discover acts no more threatening than those of concealment, the need for reformation may well have been obviated. ${ }^{145}$

If, on the other hand, the primary aim of the criminal law is to deter others, the social benefit of prosecution long after the offense may fail to outweigh other considerations. It has long been supposed that, to be effective as a deterrent, criminal sanctions must be meted out while the crime punished is fresh upon the community's mind. ${ }^{148}$ In fact, rather than be deterred at all, one contemplating the fact that $A, B$, and $C$ were able to evade detection for six years might conclude that with a little more caution he could do so forever. Even granting, however, that such a trial may afford a modicum of deterrent value, this might be offset by obstructing the reformation of those whose fear that the passage of time will afford them no sanctuary closets them forever in the underworld. The statute of limitations compels the investigative diligence which secures a speedy and-hopefully-socially useful trial, or allows none at all. 147

more particularly to the defendants ... the memories of witnesses as to events occurring many years ago are not clear.

69 F. Supp. at 815 .

People v. Ross, 325 III. 417, 156 N.E. 303 (1927) : "The very existence of the statute is recognition by the legislature of the fact that time gradually wears out proof of innocence." 325 Ill. at 421,156 N.E. at 304.

144. Suppose that a total of four witnesses become unavailable, by reason of death or otherwise, with each succeeding year, and that two are prosecution and two are defense witnesses. If we suppose further that each witness' testimony would weigh equally with the jury, the loss of equal strength to both sides may injure the government's case disproportionately, since it bears the burden of proving guilt beyond a reasonable doubt.

145. For a recent case in point, see Time Magazine, May 11, 1953, p. 24, col. 3.

146. Beccaria, An Essay on Crimes and Punisharent (London ed. 1801):

With regard to atrocious crimes, which are long remembered ... no time should be allowed; but in less considerable and more obscure crimes, a time should be fixed, after which the delinquent should be no longer uncertain of his fate. For in the latter case, the length of time, in which the crime is almost forgotten, prevents the example of impunity, and allows the criminal to amend, and become a better member of society.

Id. at 115-16.

147. While the statute of limitations insists only that the indictment be found within five years of the commission of the offense charged, 18 U.S.C. $\$ 3282$ (1958), its effect 
To the extent that vengeance is a possible goal of the criminal law, a period of limitations seems anomalous. But if the desire for retribution is an emotional response to a "disturbing event,"148 a consequence of human construction 140 rather than a dictate of $j u s$ talionis and natural law, ${ }^{150}$ the statute functions as a psychological corollary instead of an unwarranted intruder into the securing of justice. There ultimately comes a christian day when society really believes that it is better to forgive than to crush; even Victor Hugo's Inspector Javert ultimately became appalled at the role in which he had been cast. To an extent, a legislated statute of limitations is an expression of that disposition to pardon. Even if one possible reading of the criminal code permits the courts to construe the statute as running from the last overt act of concealment, society's forgiveness is more likely to run from the date of the substantive offense.

All the above objections to allowing acts of concealment to extend the indictable period are magnified by the possibility that a conspiracy involving concealment may never be terminated so as to begin the running of the statute of limitations. Will it be enough that $A, B$ and $C$ cease committing affirmative acts of concealment (such as the phone call warning in Klein) ?151 Or does each day of leaving the gun beneath the rock mark a new "overt act" in furtherance of the conspiracy? If so, will moving the rock aside cause the statute to run, or will the conspirators have to report its whereabouts to the police? When the statute becomes a bar to prosecution for the bank robbery which they were concealing, can they come forward with impunity? Or will successive conspiracies to conceal be deemed to continue onward indefinitely, all acts of concealment being construed as "in furtherance of" concealing a conspiracy to conceal? That is, in order to prove the continuance of such a conspiracy, either as a practical matter or as a matter of law, the prosecution will have to prove that there was some common animus to undertake the alleged course of concealment. ${ }^{152}$ At first blush, it might appear that after the statute had run on the underlying offense-1967, in the terms of the previous hypothetical - the reason for the concealment would dissolve. But note that up to 1967 there would be reason to conceal the bank robbery, and $e x$ hypothesi an agreement to that end would support the charge of a criminal conspiracy to de-

must be considered in conjunction with the guarantee of U.S. CONST. amend. VI that "in all criminal prosecutions, the accused shall enjoy the right to a speedy and public trial ...."

148. The expression is from Donneliy, Goldstein \& Schwartz, Crmmnal Law: Problenss in the Promulgation, Invocation and Administration of a Law of Crinces (to be published, 1961).

149. See Westerrararc, Ethical Relativity ch. 3.

150. "The Penal Law is a Categorical Imperative; and woe to him who creeps through the serpent windings of Utilitarianism to discover some advantage that may discharge him from the Justice of Punishment, or even from the due measure of it . . " KANT, PHILOSOPHY of LAw 195 (Hastie ed. 1887).

151. See note 120 supra.

152. Cf. United States v. Bufalino, 285 F.2d 408, 411-12 (2d Cir. 1960) at text accompanying notes $228-30$ infra. 
fraud. This second conspiracy being itself criminal, a need to conceal it would not expire until five years after 1967; thus between 1967 and 1972 a "third" conspiracy might be needed to conceal the second, and so ad infinitum.

If a conspiracy to conceal is held to be inherently interminable, then, in one sense, agreements "to throw sand in the government's eyes"153 will be on a par with capital offenses; the law will not offer a temporal sanctuary in either case. ${ }^{154}$ This result would be difficult to reconcile with the general policy affording longer periods of limitation to the offenses society deems more grave. ${ }^{155}$ Especially is this true if the "concealment conspiracy" does not visit such harm on society as to merit being an independent crime, but can be viewed as nothing more than a handy invention to avoid the statutory bar to prosecution for another and more orthodox offense. There are, however, two possible grounds on which such a conspiracy could be defended as an interminable offense: first, the conspiracy could be construed as a "continuing danger," the threat of which is not stamped out until disclosure, and second, each moment of failing to disclose could be construed as an overt act in furtherance of the conspiracy.

The most extreme exposition of the "continuing danger" rationale may be found in the opinion of Kaufman, J., in United States $v$. Bonnano. ${ }^{156}$ There, the substance of the conspiracy charged was that $A, B$ and $C$ agreed to endeavor to frustrate any inquiry into the nature of their meeting at Apalachin by "evasion, silence, or lies." 157 This being so, it appears that the conspiracy would have been deemed to extend so long as "anyone, including federal grand juries"108 might inquire into the meeting. Judge Kaufman was quite willing to accept the apparent consequence that "the statute of limitations for conspiracies such as are charged in this indictment are indefinitely extended,"169 because, as he understood the law, "the conspiracy should be considered alive so long as the danger of fruition lives"160_ "fruition" in this instance being nothing more dangerous to society than the possibility of its being answered evasively, if it asked certain questions.

In such cases it is not that the statute of limitations has been extended but that the ends of the conspirators were pitched far in advance by their

153. See note 123 supra and accompanying text.

154. 18 U.S.C. $\$ 3281$ (1958) ("an indictment for any offense punishable by death may be found at any time without limitation ....").

155. See 18 U.S.C. $\$ 3281$ (1958) and notes $140-41$ supra and accompanying text.

156. 177 F. Supp. 106 (S.D.N.Y. 1959), rev'd sub nom. United States v. Bufalino, 285 F.2d 408 (2d Cir. 1960), but without a discussion of the conspiracy to defraud allegation, which never reached the jury. See note 228 infra and accompanying text.

157. $177 \mathrm{~F}$. Supp. at 111 . The indictment charged conspiracy to defraud under $\S 371$, conspiracy to obstruct justice under $\$ \$ 371,1503$, and conspiracy to commit perjury under $\$ \S 371,1621$. Summarizing these allegations, Judge Kaufman distinguished Grunewald by noting that "the main objective of the conspiracy in this case was 'concealment' .." Id. at 112.

158. Such was the scope of the agreement alleged. Id. at 111 .

159. Id. at 112 .

160. Id. at 113 . 
original agreement, certainly it should be open to the government to interrupt an unlawful combination at any time before it reaches fruition..$^{101}$

In other words, suppose $A, B$ and $C$ conspire in 1950 to rob a certain bank in 1967; even if no overt act is committed within a ten year span, it might still be argued that "the danger of fruition" persists. In Bonnano, not the robbery of a bank on a certain date, but the evasion of inquiry made by "anyone" - presumably at any date-was the conspirators' goal. Thus viewed, a conspiracy to hamper government inquiry must continue so long as the government may wish to inquire into the acts concealed, which may well be forever, ${ }^{162}$ even if the conspirators have performed no overt acts in the interim. Despite the breadth of the court's dictum, however, there is meagre authority for the proposition that an indictment could be sustained without proving at least one overt act within the indictable period. ${ }^{163}$

The second doctrinal defense of an interminable conspiracy makes unnecessary frank abandonment of the overt act requirement such as the "continuing danger" theory calls for; in effect, the same result is reached by invoking a "continuing duty" to reveal, each moment of non-compliance being labelled an "overt act" in furtherance of the conspiracy. In the terms of the previous example, this rationale would require the court to find (1) that the agreement to conceal the weapon beneath the rock was a violation of, in the words of Klein, the "duty of everyone in our country to supply those facts as required by law,"164 and (2) that each day of failing to reveal it was an overt act in furtherance of the agreement. That Klein invites the first finding could certainly be maintained. The second finding could be reached as a matter of statutory construction. ${ }^{165}$ For example, a conviction for failure to register under the

161. Ibid.

162. See text following note 152 supra.

163. In Patterson v. United States, 222 Fed. 599 (2d Cir. 1915), the court denied that "it is absolutely essential that anything was done in furtherance of the conspiracy [within the indictment period]". Id. at 630 (dictum). This was supposed to follow "from Mr. Justice Holmes' illuminating and most helpful opinion in United States v. Kissel, 218 U.S. 601 (1910)." Ibid. United States v. Cohen, 145 F.2d 82, 94 (2d Cir. 1944), cert. denied, 323 U.S. 799 (1944), ascribes the same view to Kissel. While Holmes' language in Kissel is not always clear, the holding is precisely stated, and affords no support for position these later courts imputed to it. See 218 U.S. 610.

Moder Penal Code $\& 403.7$, comment (Tent. Draft No. 10, 1960) states that "if the agreement actually has vitality, that should suffice since the crime is a continuous offense." Id. at p. 147. How is "vitality" shown without being able to meet the overt act requirement, especially since "it is well settled that any act in pursuance of the conspiracy, however insignificant, is sufficient"? Id. $\S 503.5$, at p. 141 .

164. See note 132 supra and accompanying text.

165. The wording of a statute has been deemed critical in determining whether an offense is a "continuing" one for statute of limitations purposes. See Yates v. United States, 354 U.S. 298, 303-12 (1956) ; Pendergast v. United States, 317 U.S. 412, 419-20 (1942). For example, the possession of firearms is considered to toll the running of the statute under INr. REv. CODE of 1954, \& 6531. Von Eichelberger v. United States, 252 F.2d 184. (9th Cir. 1958) (possession of firearms began prior to 1950 and indictment was not found 
Selective Service Regulations has been upheld on the basis of an indictment found more than three years after the defendant's initial failure to register, notwithstanding a three-year statute of limitations. ${ }^{166}$ Over a strong dissent, the court relied upon an express provision of the regulations that "the duty of every man subject to registration to present himself for and submit to registration shall continue at all times. . ."167 Although the general conspiracy statute contains no such express provision, from Klein's reading into conspiracy to defraud a duty to supply facts to which the government is entitled, ${ }^{168}$ it would be a small step to construing that duty as a continuing one. But courts in general have been reluctant to allow such a construction, ${ }^{160}$ perhaps because it would be tantamount to removing the statute of limitations for the offense.

Eldredge v. United States, ${ }^{170}$ a prosecution for conspiracy to embezzle bank funds and to conceal the embezzlements by false entry, illustrates how realistic the possibility that either of the two approaches above might be used to create an interminable crime. ${ }^{171}$ Eldredge's last affirmative act in furtherance of the conspiracy was to conceal a $\$ 69,000$ shortage in $1927 .{ }^{172}$ Shortly thereafter he told his fellow conspirators that he wouldn't help them any longer, that he "was absolutely through and would have nothing further to do with the shortage."173 Subsequently prosecuted under an indictment found four years after

until December, 1956, held, not barred by six-year statute of limitations: "the essence of the offense as charged . . . is possession." Id. at 185. Compare Pitts v. State, $147 \mathrm{Ga}$. 801, 95 S.E. 706 (1918) (where statute of limitations made it criminal to "marry the wife or husband of another. .." period began to run from date of marriage), with State v. Sloan, 55 Iowa 217,7 N.W. 516 (1880) (statute made it an offense to "marry another person, or continue to cohabit with such ...." held, each day of cohabitation tolled the running of the statute).

See Annot., Commencenent of Period of Limitations Against Prosecution for Continuing Offense, 84 C.C.A. 519 (1908) (annotation to Ware v. United States, 154 Fed. 577 (8th Cir. 1907), note 13 supra).

166. Fogel v. United States, 162 F.2d 54 (5th Cir. 1947). Note that this is the same circuit which had decided Warren v. United States, 199 Fed. 753 (5th Cir. 1912), notes 169, 211 infra.

167. 162 F.2d at 55.

168. See note 132 supra and accompanying text.

169. See Yates v. United States, 354 U.S. 298 (1956), Pendergast v. United States, 317 U.S. 412 (1942) and United States v. Irvine, 98 U.S. 450 (1878). But see United States v. Bonnano, 177 F. Supp. 106 (S.D.N.Y. 1959). In Warren v. United States, 199 Fed. 753 (5th $\mathrm{Cir}$. 1912), where a bankrupt was charged with concealing assets from his trustee or not disclosing them in his schedule, the statute began to run from the first failure to disclose. The court relied on United States $v$. Irvine, supra, and the fact that the accused had taken no affirmative acts within the statutory period. Congress later changed the law so as to postpone the commencement of the period of limitation until the discharge in bankruptcy. See 18 U.S.C. \& 3284 (1958).

170. 62 F.2d 449 (10th Cir. 1932).

171. Note that the narrow question in Eldridge is whether one conspirator withdrew from an otherwise continuing offense.

172. $62 \mathrm{~F} .2 \mathrm{~d}$ at 450 .

173. Ibid. 
his last false entry, Eldredge pleaded the three year statute of limitations. In affirming the conviction, the Tenth Circuit noted that the type of act necessary to effect a withdrawal from a conspiracy would depend upon the nature of the crime contemplated; that if the aim of the conspiracy had been only to perform the affirmative act of embezzlement, seasonable notice to his associates that he would cease to extract funds would have been enough. ${ }^{174}$ But since "an essential part of the conspiracy planned was to conceal the shortage," expressed intent alone was not enough to constitute a withdrawal from the conspiracy: "It must be accompanied by some affirmative action which is effective."175 While the court never particularized the sort of "affirmative action" it had in mind, ${ }^{\mathbf{1 7 6}}$ the dilemma is apparent enough, would arise from any agreement to conceal and would be equally applicable to the problem of termination of the entire conspiracy: when the very essence of the crime alleged is not to reveal something, any act short of revelation will be regarded as playing the conspirators' role to the hilt.

If neither the "continuing danger" nor the "continuing duty" rationale is applicable, there is at least theoretical hope for the conspirators to prove termination of the conspiracy. Yet, even if an affirmative overt act be required within the indictable period, the burden imposed on the prosecution may be largely illusory. If the courts hold, for example, that conspiring to prevent the United States from discovering the whereabouts of the loot is a crime, then it is likely that the jury will be allowed to find that each monthly rental payment on the safe-deposit box in which it is secured is an overt act in furtherance of, and extending the indictable period of, the offense. ${ }^{177}$ In fact, if the agreement

174. 62 F.2d at 451.

175. Ibid.

176. The little metaphor the court left for prospective conspirators to mull over may have been clear enough: "A declared intent to withdraw from a conspiracy to dynamite a building is not enough, if the fuse has been set; he must step on the fuse." Id.

See Hyde v. United States, 225 U.S. 347, 369 (1912), where Mr. Justice McKenna captures much the same thought in a logic all his own:

If [the conspiracy] may continue it would seem necessarily to follow the relation of the conspirators to it must continue, being to it during its life as it was to it the moment it was brought into life. .. This view does not, as it is contended, take the defense of the statute of limitations from conspiracies. It allows it to all, but makes its application different. Nor does it take from a conspirator the power to withdraw from the execution of the offense or to avert a continuing criminality. It requires affirmative action, but certainly that is no hardship. Having joined in an unlawful scheme ... until he does some act to disavow or defeat the purpose he is in no situation to claim the delay of the law. As the offense has not been terminated or accomplished he is still offending. And we think, consciously offending, offending as certainly, as we have said, as at the first moment of his consideration, and consciously through every moment of its existence. ...

"This," he added unkindly, "is the reasoning of the Kissel Case stated in another way." Ibid.

177. All that must be shown is that the supposed overt act stemmed from the agreement; it may be wholly innocent in itself. See Braverman v. United States, 317 U.S. 49, 53 (1942). 
to hide the gun and loot is just one facet of a conspiracy to evade inquiry and detection, it would appear that the necessary overt act could be provoked whenever a suspect is found, simply by asking him a question concerning the conspiracy; an evasive answer could be construed as the required act. Of course, if the statute had run on the underlying robbery, and a conspirator under questioning felt reasonably certain that no act of his or his co-conspirators within the indictable period could be construed as in furtherance of a concealment conspiracy, he might disarm his inquisitors by replying that he had indeed robbed the bank, thus thwarting the attempt to breathe new life into the conspiracy. But the certainty which such a forthright reply presupposes will rarely be felt. ${ }^{178}$ As long as court decisions in this area remain unsettled, it would be unwise for a suspect to assume the risk of so answering. This reluctance will be increased by the fear that a jury, otherwise convinced of the guilt of the conspirators, will look very hard to find evidence of the conspiracy continuing into the indictable period. Moreover, there are factors other than fear of prosecution which militate against confessing past misconduct and which may prompt an evasive reply.

\section{Secondary Procedural Implications of Concealment}

In other procedural areas the effects of employing acts of concealment to extend the time-scope of a conspiracy may not cause such general concern to criminal defendants as the vitiating of the statute of limitations. Yet, in a given case such effects could make the difference between conviction and acquittal. With respect to venue, ${ }^{179}$ the sixth amendment's guarantee that an accused be tried in the state and judicial district "in which the offense shall have been committed"180 was reconciled in Hyde v. United States with bringing the conspirators to trial in any venue in which any one of them performed an overt act in furtherance of the crime. ${ }^{181}$ Thus, the longer a conspiracy is deemed to continue, the more is it apt to burgeon out from venue to venue through acts which may be in furtherance of the conspirators' goal only in the most tenuous sense. The doubts of the dissenters in the Hyde case that "the Constitution is to be satisfied with a fiction"182 are underscored when acts of concealing

178. See text following note 152 supra.

179. See generally Blume, The Place of Trial of Criminal Cases, 43 Micr. L. REv. 59 (1944).

180. U.S. CoNST. amend. VI :

In all criminal prosecutions, the accused shall enjoy the right to a speedy and public trial, by an impartial jury of the State and district wherein the crime shall have been committed, which district shall have been previously ascertained by law. . . . case).

181. 225 U.S. 347, 362-67 (1912) ; Brown v. Elliot, 225 U.S. 392 (1912) (companion

182. Id. at 390 (Holmes, J., dissenting). The case involved conspiracy to defraud the United States out of certain lands in California and Oregon; applications had been mailed to the defendants' lawyer who filed them and appeared on their behalf in the General Land Office in Washington, D.C. The lawyer having been indicted as co-conspirator, the trial 
what is really the gravamen of the offense may be pleaded so as to allow the government to "shop" for forums. While today there remain only traces of the regional antagonisms which led the founding fathers to protest "transporting us beyond the seas to be tried for pretended offenses,"183 there still exists a possibility of prejudice in offering an accuser an initial option as to where he shall try the accused. There is a slight variance in rules of evidence from court to court, ${ }^{184}$ and venue may be selected with an eye towards gaining the advantages of those most favorable for trying a particular case. Likewise there is a danger that venue could be selected for the animosity excited there by the circumstances of the particular offense, ${ }^{185}$ for suspected economic or social bias toward members of the defendant's class, ${ }^{186}$ or for the sake of removing the defendant from easy access to witnesses who might be able to exculpate him.187 The Federal Rules of Criminal Procedure provide for a defendant's motion

of all defendants was established in Washington. Holmes was joined by Justices Lurton, Hughes and Lamar in disapproving of this practice, but he enlisted no support either from Sir Frederick Pollock (see 1 Holmes-Pollock Letrers 196-98 (Howe ed. 1941)) or the Harvard Law Review (see Note, 26 Harv. L. REv. 83 (1912)).

183. Declaration of Independence, 1 U.S.C. at xxviii (1958).

184. This variance arises from the discretion allowed federal courts in interpreting the common law.

185. Krulewitch v. United States, 336 U.S. 440, 453 (1949) (Jackson, J., concurring) : Circumstances may even enable the prosecution to fix the place of trial in Washington, D.C., where a defendant may lawfully be put to trial before a jury partly or even wholly made up of the Government that accuses him.

His reference is to Frazier v. United States, 335 U.S. 497 (1948). Such bias was alleged in Quinn v. United States, 203 F.2d 20, 26-32 (D.C. Cir. 1952) (Bazelon, J., concurring), and Emspak v. United States, 203 F.2d 54 (D.C. Cir. 1952), proceedings for contempt of the Committee on Un-American Activities of the House of Representatives, the majority refused even to entertain affidavits purporting to show that the impact of government loyalty-security program was disqualifying upon government employees serving as grand jurors).

186. Suppose that $A, B$ and $C$ conspire to and do "go in disguise on the highway" to drag "freedom riders" from a bus (see 18 U.S.C. $\$ 241$ (1958), "conspiracy against rights of others") in a state in which veniremen are suspected to be reluctant to find evidence of such crimes convincing. $A$, subsequently in Washington, D.C. on a visit, is questioned by Justice Department officials as to the incident. If he answers evasively that, if he were on the highway, he "didn't see anything," ought the government be able to lay venue for trying $A, B$, and $C$ in Washington, alleging that the conspiracy was either (1) to violate the Civil Rights Act and conceal the violation or (2) to defraud the United States by agreeing to defeat through evasiveness any inquiry into the conspirators' conduct?

187. United States v. Johnson, 323 U.S. 273 (1944):

Very often the difference between liberty and imprisonment in cases where the direct evidence offered by the government and the defendant is evenly balanced depends upon the presence of character witnesses .... The inconvenience, expense and loss of time involved in transporting these witnesses to testify in trials far removed from their homes are often too great to warrant their use. Moreover, they are likely to lose much of their effectiveness before a distant jury that knows nothing of their - reputations.

Id. at.279. (Murphy, J;; concurring). 
to transfer the action to any other venue in which "part of" the offense charged was committed "if the court is satisfied" that "the interest of justice" would be best served thereby. ${ }^{188}$ Hopefully, this provision will curb more objectionable abuses. ${ }^{189}$ But change of venue is not a matter of right. The defendant must address his motion to the very court selected by the government, ${ }^{190}$ and the determination of that court is afforded broad deference by courts of review. ${ }^{101}$

Unlike the statute of limitations and venue, which are essentially matters of legislative determination, the formulation of federal rules governing the admissibility of evidence has been left to the courts to determine "by the principles of the common law as they may be interpreted ... in the light of reason and experience."102 The courts thus have a good deal of leverage in seeing that "artificial barriers to logically persuasive data be removed."193 It is certainly open to question whether there is not just such a barrier in the rule limiting admissibility of hearsay statements ${ }^{194}$ as against the conspiratorial group to those made by a co-conspirator "in furtherance of" the conspiracy. ${ }^{105}$ $A, B$ and $C$ are no less conspirators after their plan to rob a bank has been completed than $M$ ceases to be a murderer the moment he has murdered $D$. It is in the light of neither well-examined reason nor experience, but in transplanted principles of agency that the rule seeks justification: "When men enter into an agreement for an unlawful end, they become ad hoc agents for one

188. FED. R. CRINr. P. 21(b). Rule 21 (a) allows transfer "if the court is satisfied that there exists in the district where the prosecution is pending so great a prejudice against the defendant that he cannot obtain a fair and impartial trial ...."

189. See United States v. White, 95 F. Supp. 544 (D. Neb. 1951) (motion for transfer of venue under FED. R. CRIM. P. 21(b) granted).

190. See Holdsworth v. United States, 179 F.2d 933, 937 (1st Cir. 1950).

191. Bianchi v. United States, 219 F.2d 182, 191 (8th Cir. 1955) (motion under Fed.

R. CRIM. P. 21(a)).

192. FEd. R. CRTM. P. 26.

193. Cf. Morgan, Foreword to Moder Code of EnTDENCE at 4 (1942).

194. MODEL CODE OF Evidence rule 501 (1942):

(1) A statement includes both conduct found to the judge to have been intended by the person making the statement to operate as an assertion by him and conduct of which evidence as offered for a purpose requiring an assumption that it was so intended.

(2) A hearsay statement is a statement of which evidence is offered as tending to prove the truth of the matter intended to be asserted or assumed to be so intended except a statement made by a witness in the process of testifying at the present trial or contained in a deposition or other record of testimony taken and recorded pursuant to law for use at the present trial.

195. Often referred to as the "Fiswick Rule" from Fiswick v. United States, 329 U.S. 211 (1946). Actually it was adopted by the Supreme Court as early as Logan v. United States, 144 U.S. 263, 309 (1892). And cf. United States v. Gooding, 25-U.S. 460, 469 (1827) (dictum).

See generally Burns, Conspiracy Prosecutions in the Federal Courts, 40 J. CRIM. L. \& Crusrn. 760 (1950); Levie, Hearsay and Conspiracy, 52.Mrcm. L.- REv..1159 (1953) and Morgan, The Rationale of Vicarious Admissions, 42 HARv. L. REV. 461 (1929). 
another. What one does pursuant to their common purpose, all do . . ."190 This seems consonant with the nature of the crime alleged, though it has been justly criticized as presupposing an essential element of that which the court is convened to determine: that the defendants did enter into an agreement for an unlawful end. ${ }^{197}$ Thus, mechanical application of the rule may result in both the admission of prejudicial testimony as well as the exclusion of highly relevant evidence. The rule in its present form is undoubtedly something of a safeguard, for unlimited admissibility of vicarious admissions in a conspiracy trial would afford the prosecution an ever-widening selection of incriminating evidence, with the inevitable result that as against any given defendant the proved declaration may reflect unfairly upon his own participation in the conspiracy alleged. But this is a risk inherent in conspiracy prosecutions generally, and the fact alone that a declaration of one of the conspirators was made after the commission of the substantive offense does not make it automatically less probative or more prejudicial, with respect to his co-conspirators, than prior acts. Perhaps a less formulistic standard for admitting such testimony, one which not only looked to the time at which the declaration occurred, but encouraged a frank and careful weighing of the probative value and the prejudicial impact of each item of evidence, would promote a rational inquiry without unfairly prejudicing, and perhaps even inuring to the benefit of the defendant. Historically, the courts might have adopted such an analysis. ${ }^{188} \mathrm{But}$ the test which limits the admissibility of hearsay declarations to those made before the termination of the conspiracy has become so well established, that in order to maintain the apparent inviolateness of a rule more rigid than reason would dictate, and still bring in evidence of probative value, the courts in cases such as Lew Moy ${ }^{109}$ were forced synthetically to extend the duration of the crime so that the desired testimony could be labelled "in furtherance of" the conspirators' goal. The courts should not be condemned simply because they have felt compelled to devise a circuitous rationale to avoid the impact of a self-imposed, but doctrinally deep-seated principle, for an evaluation of the effects of extending the co-conspirators' exception to allow testimony of post-

196. Van Riper v. United States, 13 F.2d 961, 967 (2d Cir. 1926) (Learned Hand, J.).

197. Justice Jackson, concurring in Krulewitch v. United States, said:

A conspiracy is often proved by evidence that is admissible only upon the assumption that conspiracy existed. The naive assumption that prejudicial effects can be overcome by instructions to the jury . . . all lawyers know to be an unmitigated fiction. 336 U.S. 440, 453 (1959).

198. The co-conspirators' exception to the hearsay rule was conveniently adopted as the law at a series of treason trials of "fellow travellers of the French Revolution" in England in the 1790s. Trial of Thomas Hardy, 24 How. St. Tr. 200, 451-58, $473-77$ (1794); King v. William Stone, 6 T.R. 527, 101 Eng. Rep. 684 (1796), full transcript as trial of William Stone, 25 How. St. Tr. 1155, 1270 (1796); Trial of Horne Tooke, 25 How. St. Tr. 1, 74, 126 (1794). See Levie, Hearsay and Conspiracy, 52 MrcH. L. Rev. 1159, 1162 \& $\mathrm{n} .18$ (1954).

199. Lew Moy v. United States, 237 Fed. 50 (8th Cir. 1916); see cases cited at notes 30,34 supra. 
conspiracy hearsay might indeed reveal an increase in the "precision" of criminal trials. ${ }^{200}$ In all events, the courts ought to restrain themselves from indiscriminately transposing the conceptual framework by which their rules of evidence operate over into the areas of constitutional and legislative prerogative -the establishment of venue and statute of limitations requirements and the formulation of penalties for accomplices after the fact.

\section{ConcLuston}

Avowedly, the Supreme Court has pledged itself to "view with disfavor attempts to broaden the already pervasive and wide-sweeping nets of conspiracy prosecution." ${ }^{201}$ But while criminal conspiracy cases have had a way of exciting judges to bristling and picturesque condemnations, mere literary alarm has yet to prove a guarantee of effective confinement. When the rights of an accused are not crystallized in advance of trial, the possibilities for arbitrary exercise of power are increased. Especially is this true with rules such as the statute of limitations, hearsay and venue requirements, for all are fetters upon effective prosecution and, as such, are more apt to be admired in the marketplace of ideas than in the courtroom. The mythical plight of a JeanValjean, pursued eternally for a petty crime, is an effective appeal for a statute of limitations-but in the passions of real cases, a supposed influence peddler and a would-be tax evader tempted its breach. The values threatened are too critical to leave the operative effects of concealment conspiracies unresolved.

\section{Ancillary Agreements to Conceal}

The Supreme Court has apparently been in accord but, significantly, has yet actually to hold, that an agreement to commit a crime and then to conceal its occurrence can be a single criminal conspiracy. ${ }^{202}$ It may be that the present members of the Court, while not prepared to assert that such an operative extension of the crime is bad law, are going to continue to reject the theory on evidentiary grounds. But such a method of disposition has unnecessarily left citizens and prosecutors beneath the cloud of an uncertain rule of conduct, ${ }^{203}$ with unsettling repercussions in areas as far removed as self-incrimi-

200. See note 144 supra and accompanying text.

201. Grunewald v. United States, 353 U.S. 391, 404 (1957), citing Delli Paoli v. United States, 352 U.S. 232 (1957), Lutwak v. United States, 344 U.S. 604 (1953), Krulewitch v. United States, 336 U.S. 440 (1949), and Bollenbach v. United States, 326 U.S. 607 (1946).

202. Grunewald v. United States, 353 U.S. 391 (1957), notes 64-104 supra, Lutwak v. United States, 344 U.S. 604 (1953), notes 48-63 sipra, and Krulewitch v. United States, 336 U.S. 607 (1949), notes $23-39$ supra.

203. It is ironic that in introducing the Court's opinion in Hyde v. United States, 225 U.S. 347 (1911) half a century ago (see note 176 supra) Mr. Justice McKenna observed that "the attorney general assented to the granting of the writ,- he saying that "the determination of this case depends upon the principles of law governing conspiracy,' and that in view of ... the numerous prosecutions under the conspiracy statute, "it was of vital im- 
nation. ${ }^{204}$ This cloud can be dispelled only after a closer analysis than the Court has yet attempted of the various consequences of extending the duration of a conspiracy.

The statute of limitations is a valuable safeguard which has been a part of federal criminal code since its inception in $1790 .{ }^{205}$ As recently as 1957, in Yates v. United States, the Supreme Court recognized that the operation of the statute was to be determined according to "the rule that penal statutes be construed strictly." ${ }^{206}$ Clearly there is no express provision in the federal criminal code for considering as a single offense an agreement to-rob-a-bank-andto-conceal-the-robbery, or -and-to-avoid-detection. ${ }^{207}$ Should the courts then hold valid an indictment found not within five years of the robbery, but with-

portance to the United States as well as to its citizens, that these principles be definitely settled by this court.' " Id. at 355-56.

204. The uncertainty as to whether a past offense may still be indictable on account of acts of concealment raises the problem, may one plead the Fifth Amendment privilege with respect to such offense? Or will refusal to answer be contempt? In United States $\nabla$. Goodman, 289 F.2d 256 (4th Cir. 1961), appellant refused to answer certain questions relating to his business activities between 1944 and 1950, claiming he might be implicated in a continuing conspiracy, 289 F.2d at 258, relying upon the decisions in Grunewald and Forman v. United States, 361 U.S. 416, 289 F.2d at 261-62. He was ordered to answer, Chief Judge Sobeloff dissenting. The same problem appears in a denaturalization proceeding, United States v. Costello, 222 F.2d 656 (2d Cir. 1955), the court refusing to allow the witness to plead the Fifth. But see United States v. Zwillman, 108 F.2d 802, 803 (2d Cir. 1940).

205. Act of April 30, 1790, 1 Stat. 119 ch. 9, § 32.

206. 354 U.S. 312.

207. The ultimate disposition of the Grunewald case, which was a peculiarly hybrid form of prosecution in the terms of this Comment's analysis (see note 76 supra) could be defended upon a fair reading of the statute, although not a reading made explicit by the Court.

Professor A. Goldstein, in his definitive article on $\S 371$, Conspiracy to Defraud the United States, 68 YaLE L.J. 405 (1959), allows that the "ordinary" meaning would endow "defrauding" with two minimal characteristics: "first, there must be a falsehood, a lie" which might extend to "an affirmative misstatement which affords a basis for judgment" and "second, the lie must be purposive in nature ... with the defrauder seeking a benefit from the government which would not be conferred upon him if he revealed the truth." Id. at 455-56. In the terms of Grinewald, a decision not to prosecute was a meaningful "bencfit" so long as the statute had not run on the allegedly fraudulent returns, at least in the sense that it shielded the defrauders from prosecution. If a conspiracy existed toward affording the government the basis for a corrupt judgment, and if, on retrial, "affirmative misstate.. ments" in furtherance of this goal had been found within the indictment period, the behavior would fairly have fallen within the legislative prohibition.

Interesting questions of statutory construction might arise in the instance of certain crimes, e.g., conspiracy to kidnap, where one joined the conspirators after the victim had been transported in interstate commerce, but while he was being held for ransom. In Shannon v. United States, 76 F.2d 490, 492 (10th Cir. 1935) the court took the position that "The substantive offense consists of two constituent elements. They are transporting an abducted person in interstate commerce and holding him for ransom and reward. Transportation ... is an essential element, but the other is a constituent ingredient." The kidnapping statute, 18 U.S.C. \& 1201(a) (1958) reads: "Whoever knowingly transports in 
in five years of the last overt act of concealment? The answer should be an unequivocal "no"; whether or not concealment subsequent to the substantive offense arose out of an "express original agreement" ought to be as irrelevant in the conspiracy setting as the Supreme Court has considered it in the setting of prosecutions for substantive crimes. ${ }^{208}$ While the conspirators' agreement is the initial source for determining the conspiratorial goal, the operative life of the offense must ultimately be delimited by the congressional definition of the crime itself; ${ }^{200}$ if there is truth in the Supreme Court's observation that steps to avoid detection have been "a concomitant, certainly, of every crime since Cain attempted to conceal the murder of Abel from the Lord, ${ }^{3210}$ then Congress must be supposed to have taken the likelihood of such acts into account in arriving at the statutory period. Congress is free to make, and has made special statutes of limitations where it has found doing so desirable. ${ }^{211}$ For the courts to fashion from loose conspiracy doctrine further provision for acts of concealment would usher in all the inequities of distegarding the statute for the substantive offense.

The prosecution's use of acts of concealment to extend the operative life of a conspiracy seems most flagrantly unjustifiable in those cases where a party

interstate . . . commerce, any person who has been . . . kidnapped . . . and held for ransom ...." The past tense, viz., "held," detracts from the construction in Shannon. But see note 216 infra.

208. See Pendergast จ. United States, 317 U.S. 412 (1943).

209. As the Supreme Court seems to have done in Pendergast v. United States, 317 U.S. 412 (1943) and Yates v. United States, 354 U.S. 298 (1957). The Moder PeNal Code $\S 1.07$ (4) (Tent. Draft No. 5, 1956) suggests that

An offense is committed either when every element occurs, or, if a legislative purpose to prohibit a continuing course of conduct plainly appears, at the time when the course of conduct or the defendant's complicity therein is terminated.

The Court's interpretation in the Yates case of the word "organize" is a near extreme example of demanding that the legislature, if it wants to undertake the creation of a continuing offense, must do so unequivocally.

210. Grunewald v. United States, 353 U.S. 391 (1957).

211. Warren v. United States, 199 Fed. 753 (5th Cir. 1912) held that where a bankrupt was charged with concealing assets from his trustee, the concealment consisting in not disclosing his schedule, the statute began to run from the first failure to disclose. Congress changed the law in 1938 so as to commence the period of limitation only from the discharge in bankruptcy. See 18 U.S.C. § 3284 (1958).

Two means by which the legislature can make explicit that a crime is to be a continuing one are illustrated in the administration of the Internal Security laws. 64 Stat. 1002 (1950), 50 U.S.C. \& 794(c) (1958) provides that members of Communist organizations having a duty to register with the Subversive Activities Control Board shall "be punished for each such violation by a fine of not more than $\$ 10,000$, or imprisonment for not more than five years" and that, "each day of failure to register ... shall constitute a separate offense"; thus, failure to register for one month could lead to penalties of 150 years imprisonment and $\$ 30,000$. A somewhat more lenient treatment is afforded "persons trained in foreign espionage systems" whose hesitancy about filing a statement to that effect with the Attorney-General is "a continuing offense for as long as such failure exists, notwithstanding any statute of limitations to the contrary." 70 Stat. 900 (1956), 50 U.S.C. $\S 856$ (1958). 
who associates with the conspirators after the attainment of the substantive goal is charged with conspiracy to commit a substantive offense already committed. ${ }^{212}$ Such a practice would allow the latecomer to be liable for punishment as severe as execution, ${ }^{213}$ in apparent disregard of the policies of Congress in establishing limited penalties for accessories after the fact. ${ }^{214}$ A 1946 Supreme Court decision does seem to indicate, however, that the early kidnapping cases have lost their vitality, ${ }^{215}$ but the issue is by no means settled. ${ }^{210}$

\section{Conspiracies to Conceal}

When an agreement to conceal is viewed not as ancillary to and extending a criminal conspiracy to commit a substantive offense, but as an independent

212. See cases at note 8 supra.

213. One convicted of conspiracy to kidnap, for example, could be sentenced to death if the victim "had not been liberated unharmed." 18 U.S.C. $\$ 1201$ (1958).

214. 18 U.S.C. $\$ 3$ (1958)

Whoever, knowing that an offense against the United States has been committed, receives, relieves, comforts or assists the offender in order to hinder or prevent his apprehension, trial or punishment, is an accessory after the fact.

Except as otherwise expressly provided by any Act of Congress, an accessory after the fact shall be imprisoned not more than one-half the maximum term of imprisonment or fined not more than one-half the maximum fine prescribed for the punishment of the principal, or both; or if the principal is punishable by death, the accessory shall be imprisoned not more than ten years.

And see 18 U.S.C. $\$ 1202$ (1958),

Whoever receives, possesses, or disposes of any money ... which has at any time been delivered as ransom ... in connection with a violation of section 1201 of this title, knowing the same to be ... ransom . . . shall be fined not more than $\$ 10,000$ or imprisoned not more than ten years or both.

215. Bollenbach v. United States, 326 U.S. 607, 611 (1946) ("Bollenbach could not properly be convicted for the offense for which he was . . convicted, namely, for having conspired to transport securities across State lines merely on proof that he was a "fence"; i.e., helped to dispose of the stolen securities after the interstate transportation had concluded.")

216. See Grunewald v. United States, 353 U.S. 391, 405 (1957) ("kidnappers in hiding, waiting for ransom, commit acts of concealment in furtherance of the objectives of the conspiracy itself, just as repainting a stolen car would be in furtherance of a conspiracy to steal; in both cases the successful accomplishment of the crime necessitates concealment" (emphasis added).

The number and variety of crimes which involve interstate transportation as an element are rather extensive. Aside from such celebrated items of commerce as automobiles, 18 U.S.C. \& 2312 (1958) and women, 18 U.S.C. \$ 2421, the federal criminal code extends its reach to the transport of bodies of dead birds $(\$ 43)$, cattle ( $\$ 2316)$, radioactive materials ( $\$ 832$ ), water hyacinths $(\$ 46)$, obscene, lewd, lascivious or filthy books $(\$ 1462)$, fireworks $(\S 836)$, artificial teeth ( $\$ 1821$ ), prison made goods ( $\$ 1761)$, slaves, ( $(1588)$, lottery tickets $(\S 1301)$, strikebreakers $(\S 1231)$, liquor $(\S 1262)$, persons who have been held for ransom $(\S 1201)$, securities ( $\$ 2314)$, and mongooses of the species Herpestes auropunctatus ( $\$ 42$ ) (all 1958; the list is not exhaustive).

Such a breadth of activities being involved, the determination of whether, and to what extent, a crime of interstate commerce or national import may extend beyond the crossing of the boundary will be a decision of widefelt concern. 
conspiracy to defraud the United States, a new difficulty arises. No longer may the problem of limiting the crime's duration be disposed of by an appeal to a fair reading of the statute, and a declaration that, after the substantive offense is committed, subsequent acts of concealment are legally inoperative. For when the proscribed goal of the conspirators is not a substantive offense elsewhere listed in the code, but, in effect, concealment itself, there is no doctrinal justification for terminating the conspiracy so long as acts of concealment continue. Undeniably, the government has the right to protect itself against conspiracies which are designed to hamper its operations. But there is a spectrum of acts which may roughly be deemed "concealment," some of which lie within the area of personal freedom and some within that of the state's duty to maintain order. For example, one may not be compelled to incriminate himself ;17 yet he may not request another to commit perjury on his behalf. 218 Congress has made specific provisions, independent of the conspiracy to defraud statute, prohibiting those acts contributing to "concealment" which most directly undermine the functioning of the governmental system. Among other offenses, it is unlawful to conspire to intimidate witnesses, ${ }^{219}$ to bribe witnesses, judges, or public officials, ${ }^{220}$ to file false or fraudulent statements, ${ }^{221}$ to hinder the apprehension of an offender, ${ }^{222}$ and to conspire to impede a federal officer. ${ }^{223}$ In sum, by enacting these relatively narrowly defined laws Congress has presumably attempted to strike a balance between the individual's right to privacy and the effective operation of the government.

The modern law of conspiracy was largely evolved by judges. ${ }^{224}$ The courts might now take advantage of the loose framework in which conspiracy may be expanded to shift this balance, to outlaw acts of concealment which are further and further from direct conflict with governmental operations. Certainly there are ample phrases within the sweepingly broad dicta of past cases to enable courts to construct a conspiracy to defraud out of acts of concealment which impair the efforts of government agents to discover whether there has been a crime. ${ }^{225}$ One result of so extending the law might be to increase the efficiency of federal agents. Criminals might take care not to take any steps to cover up their crimes, not to exchange stolen currency, not to destroy correspondence, not to do whatever it is which the courts say may be unlawful under conspiracy to defraud. But the prospect that criminals will be so swayed is hardly

217. U.S. Const. amend. V.

218. U.S.C. § 1622 (1958).

219. U.S.C. $\S \S 1503-5,7$ (1958).

220. 18 U.S.C. $\$ \$ 201-23(1958)$.

221. 18 U.S.C. $\$ \$ 1001-26$ (1958).

222. 18 U.S.C. $\S \S 3,4,792,1071$ (1958).

223. 18 U.S.C. $\$ 372$ (1958). See Finn v. United States, 219 F.2d 894 (9th Cir. 1955), cert. denied, 349 U.S. 906 (1955).

224. Krulewitch v. United States, 336 U.S. 440, 456 (1949) (Jackson, J., concurring).

225. See Haas v. Henkel, 216 U.S. 462 (1910) and Hammerschmidt v. United States, 265 U.S. 182 (1924), at note 83 supra. 
a likely one. It is difficult to imagine that founding a conspiracy upon any acts short of perjury, obstruction of justice, and related crimes already and expressly made unlawful, would have any effect of facilitating prosecution other than by constructing a guise by which the statute of limitations may be avoided and venue requirements ignored for an underlying offense. Moreover, where the supposed object of the concealment is not a provable offense, as in the Klein case, and conviction is based on the theory that the government was prevented from discovering whether or not there had been a violation of law, the result is more objectionable still.226 The duty which the defendants in Klein violated could no more exactly be located than in the "brooding omnipresence" of the Internal Revenue Code; the very joining of the amorphous terms "honestly" and "that to which the government is entitled" forges a weapon the coercive force of which is lodged in vagueness. The investigative branch of the government might be permitted a power of inquisition more potent than could be had under the safeguards of a grand jury; individuals guilty of no crime might be compelled to divulge all they know about various shades of misconduct from fear that the facts sought are those to which the state is entitled "under our law." Conspiracy, not contempt, would be the deserts of contumacy.

Just as ancillary agreements to conceal may die from judicially imposed evidentiary burdens, ${ }^{227}$ it is possible that the courts, while allowing that certain agreements to conceal could constitute a conspiracy to defraud, are going to demand such an imposing quantum of evidence before they "see" one that their existence will be academic. Such may be the significance of the Second Circuit's decision in United States v. Bufalino. ${ }^{228}$ There, the same circuit which decided the Klein case was faced with alleged conspiracies to commit perjury and to obstruct justice, based upon the defendants' concealment of the nature and purposes of the now celebrated Apalachin, New York meeting. As in the Grunereald case, the majority opinion stressed the insufficiency of the evidence, the government having failed "to prove that the conspirators intended to lie under oath or that they envisioned proceedings where they would be called upon to testify under oath."229 The court's opinion manifests a warm distaste for the government's theory of the case. Yet, by stressing that the prosecution failed to show defendants "knew or should have known" that there

226. United States v. Klein, 247 F.2d 908 (2d Cir. 1957), cert. denied, 355 U.S. 924 (1958). See text at notes 114-17 supra.

227. See note 95 supra.

228. 285 F.2d 408 (2d Cir. 1960). The indictment charged that the defendants, knowing they would be questioned concerning the nature of their meeting, conspired to give false material information to investigating bodies and give "false, fictitious, fraudulent, vague, evasive and manufactured material testimony under oath . . " 285 F.2d at 410-11 n.10. When reported, at an earlier stage, sub nom. United States v. Bonnano, 177 F. Supp. 106 (S.D.N.Y. 1959), at notes 156-63 supra, a conspiracy to defraud charge was incorporated in the indictment. It was never given to the jury however. See 285 F.2d at $410-11$ n.10.

229. 285 F.2d at 411-12. 
would be a judicial investigation, the decision foreshadows the prosecution's having to fall back upon conspiracies to defraud in the future; for while the requirement that there be a judicial setting in the offing is a pre-requisite to prosecution for conspiracy to obstruct justice and to commit perjury, ${ }^{230}$ an allegation of conspiracy to defraud would not have forced the government to prove that defendants knew such an inquiry was pending. What would the Second Circuit have said and what might they say in the future, if the prosecution had conceded arguendo that defendants could not have foreseen-and so could not have conspired to interfere with-a judicial inquiry, but more easily could have foreseen an investigation by federal law enforcement officials and therefore conspired to defraud the United States by their evasiveness, just as the defendants in Klein had defrauded the Treasury Agents by theirs?

The state is not impotent in the face of crime. Investigators have the machinery to arm themselves with warrants on a showing of "good cause." If sufficient evidence is uncovered, a grand jury may be convened, and an orderly inquisition begun. No doubt, without the weapon of concealment conspiracies, crimes will go uncovered which might otherwise be revealed. And some, whose lives seem to be spent tempting the outer reaches of the law, will never fall within its ambit. But ours is a society which has always looked to values beyond efficiency in bringing wrongdoers to the bar of justice.

\section{Christopher D. Stone}

230. A requirement which has been well established at least as early as Pettibone v. United States, 148 U.S. 197, 207 (1893) ("such obstruction can only arise when justice is being administered,"). In United States v. Perlstein, 126 F.2d 789 (3d Cir. 1942), the court noted that where conspiracy to obstruct justice is charged, it presupposes "a proceeding before a United States Commissioner or a district court which [the conspirators] expect or fear will be instituted." Id. at 795. See United States v. Scoratow, 137 F. Supp. 620 (W.D. Pa. 1956) (obstruction of F.B.I. did not constitute obstruction of justice: "The Federal Bureau of Investigation is an investigative rather than a judicial arm of the government. It does not 'administer justice' within the meaning of Section 1503"). But did the "evasiveness" and "position clinging" of the defendants in Klein with respect to Treasury Agents differ materially from the "evasive" responses given investigators in Bufalino? See 285 F.2d at $413-14$.

†Second Year Student, Yale Law School. 